\title{
ČESKÉ KRAMÁŘSKÉ TISKY - POKUS O DEFINICI A TYPOLOGII
}

\author{
Jakub Ivánek (Ostrava)
}

\section{Czech Chapbooks (kramářské tisky) - an Attempt at Their Definition and Typology}

\begin{abstract}
The paper focuses on the issue of a relatively wide range of kramářske tisky - the medium of Czech popular literature of the Early Modern period and the 19th century. They mostly contained kramárské písně (Czech equivalent for broadside ballads), which are currently in the spotlight of Czech research interest. Kramářský tisk can also be defined by means of equivalents in other languages. The English term chapbooks, for example, may be helpful in emphasising the commercial focus of this literature (kramárské tisky could be literally translated as 'chapman prints'). Although the English term cannot be clearly defined either, researchers generally come to an agreement that it is a publication of booklet character, of smaller extent as well as format (usually octavo or smaller, made of no more than three sheets of paper or having up to 99 pages). It was distributed by tradesmen at fairs, by colportage or soliciting. It was cheap (both in terms of production and price) and it brought what the broad spectrum of readers in towns and later in the countryside demanded - popular reading in the true sense of the word. It is complicated to include popular histories (knižky lidového čteni) in the comparison - they fit most of the features above, but they were made by folding and joining more sheets of paper and greatly exceed the imaginary limit of 99 pages. Therefore, this paper also deals with boundary media, which surpass the defined extent but principally are still chapman goods (i.e. small-format books of various lengths distributed at fairs and by soliciting). The text of the study draws attention to the appearance and development of certain types of kramárské tisky of both religious and secular content. For a better illustration, many of these types are mediated by an image.
\end{abstract}

Keywords: kramářské tisky - chapbooks - cheap prints - popular prints - early modern literature - literature of the 19th century

Kramářské písně jako významný fenomén raně novověké kultury se poslední dobou těší vědeckému zájmu. Důkazem toho je nejen rostoucí počet tištěných katalogů různě velkých sbírek, ${ }^{1}$ ale také edice textů, ${ }^{2}$ a především projekt NAKI Kramářské písně v brněnských historických fondech, který $\mathrm{v}$ současnosti řeší společně Masarykova univerzita, Etnologický ústav AV ČR, Moravské zemské muzeum a Moravská zemská knihovna. Výstupy tohoto projektu jsou např. konference, ${ }^{3}$ výstavy s doprovodnými katalogy ${ }^{4}$ a odborná monografie $\mathrm{v}$ angličtině. ${ }^{5}$ Ostatně i číslo periodika Acta Musei Nationalis Pragae - Historia litterarum, které držíte $\mathrm{v}$ rukou, je dokladem současné obliby kramářských písní jako badatelského tématu.

Ačkoli kramářské písně představují v českém prostředí nejběžnější typ kramářského tisku, jsou jen jedním z literárních artiklů někdejšího kramářského obchodu. Jiné typy kramářských tisků, které tvoří poměrně pestrou skupinu tištěných médií, stále zůstávají stranou zájmu. O tomto upozadění svědčí napřr. fakt, že v Národopisné encyklopedii se nachází heslo „kramářská píseň“, nikoli už však „kramářrský tisk“" třebaže některé typy tohoto tištěného zboží se zde objevují jako samostatná hesla, často bez vazby na kramářský charakter takového zboží. ${ }^{6}$ Naproti tomu kniha Luboše Kafky o poutovém umění obsahuje kapitolku s názvem Kramářské tisky, ovšem ta je věnována převážně kramářské písni, tř̌ebaže zmiňuje také kramářsky tištěné modlitby. ${ }^{7}$ Na slabší zájem o nepísňové kramářské tisky upozornila v minulosti Štěpánka Běhalová, když hovořila o kramářské produkci Landfrasovy jindřichohradecké tiskárny, jež byla převážně náboženská ( $88 \%$ produkce) a zahrnovala i vysoký podíl nepísňové tvorby (přes $22 \%$ ), jež byla podle ní častější právě v oblasti náboženských tisků (modlitby). ${ }^{8}$

V následujícím textu se tedy pokusím představit nepísňové typy kramářských tisků, s nimiž se můžeme v českých sbírkách setkat. Vyjdu především z největší české sbírky kramářských tisků, která je v držení Knihovny Národního

\footnotetext{
KOPALOVÁ - HOLUBOVÁ 2008; HOLUBOVÁ 2012, 2017; SKOŘEPOVÁ 2016, DRAGONOVÁ - SZTURCOVÁ 2019.

SKOŘEPOVÁ 2019; MALURA - IVÁNEK 2019.

3 Mezinárodní konference Proměny české kramářrské písně - media, tradice, kontexty proběhla v Brně 11.-13. září 2019.

${ }^{4}$ Zatím proběhla v Moravském zemském muzeu výstava světských kramářských písní s názvem Do Brna široká cesta. Kramářské písně se světskou tematikou (záŕí 2020 - březen 2021). Recenze této výstavy a stejnojmenného katalogu (GLOMBOVÁ 2020) se nachází v tomto čísle periodika Acta Musei Nationalis Pragae - Historia litterarum. Další výstava, o kramářské písni náboženského, respektive duchovního obsahu, je plánována na jaro 2022.

5 FUMERTON - KOSEK - HANZELKOVÁ 2022.

${ }^{6}$ BROUČEK - JEŘÁBEK 2007.

7 KAFKA 2009, s. 197-203.

${ }^{8}$ BĚHALOVÁ 2003, zejm. s. 548, 552-553.
} 
muzea, avšak přihlížet budu rovněž $\mathrm{k}$ dalším navštíveným českým a moravským sbírkám.

Než ale přistoupíme k prezentaci zaznamenaného materiálu, je nutné stanovit definici pojmu „kramářský tisk“, jeho rozsah a vztahy $\mathrm{k}$ cizojazyčným ekvivalentům. Kramářské tisky tvoř́i pomyslnou skupinu cenově levných, tiskem nenáročných a obsahem populárních tisků, které byly šířeny kramáři, tedy obchodníky prodávajícími své zboží v přenosných boudách či na lavicích během trhů a poutí. Dalším možným způsobem prodeje takového materiálu byl prodej podomními obchodníky, kteří distribuovali řadu produktů městské kultury na venkově. Některé tisky bylo možné (zvlášt' v 19. století) koupit také v „kamenných obchodech“ tiskaře, nakladatele či přímo u autora. Kramářské tisky jsou od původu městskou kulturou, jež se vyvinula z módy letáků, které hýbaly společenským děním v době předbělohorské. ${ }^{9} \mathrm{Na}$ vesnici zrrejmě pronikaly pomalu, ale nárůst této produkce v průběhu 18 . století a její vrchol zhruba v půlstoletí 1775-1825 dokládají, že kramářské tisky se postupně staly vedle náboženských příruček hlavním čtivem stále více gramotných venkovanů. Jejich popularita po značnou část 19. století přispěla $\mathrm{k}$ přeživání starých literárních forem na vesnici, kde v této době mluvíme obecně o lidovém, v podstatě opožděném baroku. ${ }^{10}$

Definující přívlastek kramářský upřednostňuje komerční charakter této tvorby. Není to nic překvapujícího, uvážíme-li, že kramářské tisky patř́ do oblasti populární literatury a právě „komercionalizace populární kultury“ je dle Petera Burka dobovým př́znakem završení lidové kultury před koncem její tradiční podoby. ${ }^{11}$ Ostatně i anglický ekvivalent českého termínu kramářské tisky má podobný charakter. Anglické slovo chapbooks, označující právě skupinu levných populárních tisků, ${ }^{12}$ bývalo někdy chybně vykládáno jako „levné knížky“ (cheap books); první komponent tohoto slova je pritom staré anglosaské slovo pro obchod (céap), které slyšíme také v zastaralém označení obchodníka (chapman). A ten má blízko k českému kramáři. Označení chapbooks bývá tedy vykládáno jako zkratka spojení chapman books. ${ }^{13}$ Okolnosti prodeje slyšíme i v jiných národních ekvivalentech pojmu kramářský tisk - v mad'arském ponyva (levné plátno, na němž byly při prodeji na trhu položeny), ${ }^{14}$ v norském a dánském skillingstrykk či švédském skillingtryck (vlastně ,šilinkový tisk“, tedy stojící jeden šilink), ${ }^{15}$ ve španělském spojení literatura de cordel (,„šňůrová literatura", protože tisky byly během prodeje na trhu vystaveny zavěšené na šňůrách), ${ }^{16}$ ale také v dalším anglickém ekvivalentu penny print (,tisk za penci“), třebaže šlo vesměs o tisky prodávané za dvě až šest pencí (dle rozsahu). ${ }^{17}$

Vzhledem k prŕbuznosti pojmů chapbooks a kramářské tisky může překvapit fakt, že anglické paralele české kramářské pisně se říká zcela jinak - broadside ballad. Tento fakt je dán odlišnou podobou tohoto fenoménu v kultuře raně novověké Anglie, kde šlo výhradně o velký jednolist potištěný pouze $\mathrm{z}$ jedné strany (broadside), aby mohl sloužit coby plakát, at' už lepený na zdech ulic, nebo v interiéru (méně častý byl oboustranný tisk, kterému se rríká broadsheet, avšak i ten byl plakátového rozměru). ${ }^{18}$

Tuto podobu známe i z českého a německého prostředí doby reformace. Ve střední Evropě se však v průběhu 17. století ustálila vesměs menší, sešitová podoba tisků, kdy různými způsoby přehybu a rozřezáním tiskového archu ${ }^{19}$ vzniká sešitek, který mívá většinou čtyři (případně jen dva) až 16 listů, a to nejčastěji ve velikostech osmerky (charakteristické pro německé tisky) a šestnácterky (typické pro českou produkci). ${ }^{20} \mathrm{~V}$ českém prostředí se vzhledem k proměňování obsahu, adresáta i podoby média zpravidla sahá k pojmovému rozlišení. Pro předbělohorskou produkci (větší a typograficky náročnější tisky o aktuálních událostech, doklad ideologických střetů doby, adresátem byli především měšt’ané, ale také šlechta) se užívá termín leták. Pobělohorské produkci, ovlivněné po obsahové stránce omezením svobod a dlouho tíhnoucí k náboženským látkám, říkáme kramářský tisk. Postupné zmenšení formátu, které vyhovuje soukromému užívání obyčejným člověkem, ${ }^{21}$ ale také distribuci (menší tisky se lépe převážejí/přenášejí), odpovídá plně komerčnímu charakteru tohoto zboží, které v označení slyšíme.

V německém prostředí se naproti tomu užívají pro starší i mladší podobu fenoménu tytéž termíny - Flugblatt (většinou jednostranně potištěný jednolist) a Flugschrift (tisk sešitového charakteru). ${ }^{22}$ Tato pojmenování jsou pak přítomna i v kompozitech označujících německou kramářskou produkci písňového charakteru (Flugblattlied, Flugschriftlied). ${ }^{23}$

\footnotetext{
${ }^{9}$ Ke kultuře letáků zatím nejobsáhleji HUBKOVÁ 2010. O letácích jako předstupni kramářských tisků v poslední době MALURA $2019,2022$.

${ }^{10}$ Termín ,selské baroko“, užívaný v oblasti architektury, nivelizuje značně rozvrstvenou venkovskou společnost.

${ }^{11}$ Srov. BURKE 1978, s. 244-246, 250-259 (český překlad: BURKE, s. 255-257, 264-268); BURKE 1984, s. 10.

${ }^{12} \mathrm{~V}$ angličtině se setkáváme též s označením cheap prints („levné tisky“) či popular prints (,„populární tisky“), ačkoli angličtina vnímá slovo print jinak než čeština slovo tisk. Print totiž v užším, původním smyslu slova označuje zejména obrazové tisky (tedy dřevoryty, mědiryty apod.) bez významnějšího textového doprovodu. Slovo se však začalo uživat také jako zkratka pro spojení printed item („,tištěné zboži“; srov. ATKINSON ROUD 2019, s. xii).

${ }^{13}$ ATKINSON - ROUD 2019, s. xi.

${ }^{14}$ MIKOS - CSÖRSZ 2019, s. 284

${ }^{15}$ BRANDTZÆG - STRAND 2019, s. 139.

${ }^{16}$ SINCLAIR 2019, s. 9-10.

${ }^{17}$ NEWCOMB 2011, s. 474.

${ }^{18}$ Srov. např. ATKINSON - ROUD 2019, s. xi. - Ostatně, odlišnost anglického a českého prostředí tkví i v tom, že anglická kultura broadside ballads zůstala po značnou část svého vývoje kulturou městskou, zatímco české kramářské písně pronikly s postupem gramotnosti i na vesnici.

${ }^{19}$ Srov. heslo Arch v online Encyklopedii knihy Petra Voita, dostupné z: www.encyklopedieknihy.cz

${ }^{20}$ Srov. hesla Osmerka, Šestnácterka, př́ípadně Formát knihy v online Encyklopedii knihy Petra Voita, dostupné z: www.encyklopedieknihy.cz

${ }^{21} \mathrm{~V}$ českém prostředí typická kultura špalíčkủ, tedy konvolutů sešitých kramářských tisků (většinou písní), jež představovaly pro leckterého člověka jedinou knihu, kterou vlastnil.

${ }_{22}^{2}$ Viz např. heslo Flugblatt v encyklopedii RDK Labor (COUPE 2003).

${ }^{23} \mathrm{~K}$ rozlišení těchto termínů a populárního německého pojmu Bänkelsang srov. IVÁNEK 2017, kde čtenář najde odkazy na starší literaturu. Srov. také příspěvky v chystané knize FUMERTON - KOSEK - HANZELKOVÁ 2022.
} 
Letákový charakter tisku, upřednostněný v německém označení, se ozývá i v polském termínu druki ulotne (,letákové tisky“"), třebaže kramářrkým písním Poláci říkají především pieśni jarmarczne (,jarmareční písně“), méně často (snad pod českým vlivem) pieśni kramarskie. Slovenská věda naopak prosazuje (zřejmě pod německým vlivem) slovo leták i pro označení písňového materiálu - letákové piesne. ${ }^{24}$

Vrat'me se však k náplni pojmu kramářský tisk. Co vše do něj patří? Respektive, co označuje? Jaká je jeho definice? I v tomto nám může být významně nápomocen anglický termín chapbook a jeho vymezování, třebaže i to je nejednoznačné. Řekli jsme si už, že anglické kramářské písně (broadside ballads) byly většinou jednostranně potištěné rozměrné jednolisty. Naproti tomu pojem chapbook označuje striktně řečeno jeden oboustranně potištěný arch (př́ípadně půl či jeden a půl archu), který byl následně složen do podoby malého sešitku (booklet), běžně (podle jeho velikosti) o osmi až 32 stranách. Vedle toho je však označení vzhledem k obsahové náplni samotného termínu chapbooks (který lze do češtiny přeložit jako „kramářské knížky“) spojováno s tisky, které byly šířeny trhovým, pouličním či podomním prodejem, a to i takové, které mají více stran, a byly tedy tištěny na více než jeden tiskový arch. Dle výzkumů Margaret Spufford a Tess Watt ${ }^{25}$ rozlišovala dobová obchodní terminologie kolem roku 1680 tři typy komerčního tiskařského zboží: small books (,malé knihy“ složené z jednoho až jednoho a půl archu), double-books (,dvojknihy“ složené maximálně ze tří archů) a histories (,historie“, které byly delší, ale z obchodního hlediska stejně zaměřené tituly). Zvlášt' $\mathrm{u}$ posledně jmenované skupiny (histories), které v českém prostředí tradičně říkáme knižky lidového čtení (nicméně $\mathrm{v}$ raném novověku byly i v českém prostř̌edí běžně nazývány historie), se badatelé v zařazování mezi chapbooks neshodují. Tzv. na vážkách budeme i v prrípadě českého materiálu (viz níže). V současnosti bývá termín chapbooks uživán zejména pro tisky šířené „kramáři““ až do rozsahu 99 stran či tř́ složených tiskových archů. ${ }^{26}$ Shrneme-li zjištěné, klíčová je tedy podoba (sešitek), rozsah (maximálně tři tiskové archy nebo 99 stran) a komerčnost (tisky, které se prodávaly širokému publiku).

V českém prostředí nacházíme dle této definice různé typy kramářských tisků. Kramářské písně jsou jednoznačně jejich nejběžnějším typem - v muzejních sbírkách drtivě převažují. ${ }^{27}$ Převaha písňových tisků souvisí zřejmě se všeobecnou oblibou hudby a zpěvu v české historii. Dobře známa je také početní převaha náboženských kramářských písní, kterou si lze vysvětlit všeobecnou náklonností prostého člověka $\mathrm{k}$ duchovnímu chápání a prožívání světa. ${ }^{28}$ Není tedy př́kvapivé, když velkou část populární kultury nejširších vrstev obyvatelstva spoluurčovaly artefakty související s náboženskou vírou, a to platí i pro kramářské tisky obecně. Značný vliv zde měla rovněž obliba poutí. ${ }^{29}$ Velké procento náboženských kramářských písní (ale i jiných typů kramářských tisků) souvisí svým určením právě s poutěmi a poutě byly také jedním z přirozených odbytišt' kramářského zboží. ${ }^{30}$

Kramářským písním a jejich možnému žánrovému rozdělení (zejména těch náboženských) jsme se věnovali už dříve. ${ }^{31}$ Celkově lze shrnout, že se pohybují ve třech základních žánrových skupinách: Jednu tvoří písně vyprávěcí, které slouži ke sdílení příběhů, at' již náboženského, či světského charakteru. Druhou skupinu představují písně rozjímavého a reflexivního ladění (individuální modlitby, lamenty, vyznání, ale také reflexe individuálních osudů i dobových jevů; vesměs mají mluvčího v 1. os. sg.). Třetí skupina je naopak charakteristická kolektivním mluvčím či adresátem a patř́ sem zejména oslavné písně (mezi náboženskými převažují oslavy svaté osoby, ale také prosby kolektivu k ní směřované; mezi světskými jde o rozličné chvály osob, stavů, věcí, jevů). Oslavnost bývá vlastní i řadě poutnických písní, které střídají kolektivní i individuální mluvčí i adresáty, repliky poutníků i svatých osob. Nyní však nechejme písňový materiál stranou a pokusme se o zaznamenání nepísňové produkce, jež se objevovala mezi tištěným zbožím kramářů.

Následující rozdělení si neklade nárok na definitivní typologické rozlišení veškerého materiálu kramářských tisků. Vycházím zejména $\mathrm{z}$ dochovaného materiálu, který bývá do sbírek kramářských tisků řazen a zároveň tomuto zařazení odpovídá svým původním určením (tištěný materiál určený k prodeji), a snažím se respektovat zavedené kategorie a termíny, s nimiž knihověda, literární historie, etnografie a další disciplíny pracují. Proto nejde o dělení dle jediného kritéria a uvedené skupiny se mohou prostupovat vzájemně (např. modlitby a pověrečné tisky, $\mathrm{z}$ nichž některé mají rovněž charakter modlitby), nebo mohou být reálně širší, než dovolují meze termínu kramářský tisk (např. svaté obrázky nemusely být jen tištěné, ale také malované; pověrečné tisky jsou zase pevně svázány s dalšími artefakty lidového náboženství, které mají odlišný materiálový charakter).

Vedle kramářských písní nacházíme ve sbírkách kramářských tisků často následující tiskové typy: Náboženskou

\footnotetext{
${ }^{24}$ DROPPOVÁ - KREKOVIČOVÁ 2010, s. 19. Starší slovenská literatura však pracuje s termíny jarmočné a pútové tlače (srov. KLIMEKOVÁ 1996).

${ }^{25}$ Shrnuje NEWCOMB 2011, s. 473-474.

${ }^{26}$ ATKINSON - ROUD 2019, s. xi.

${ }^{27} \mathrm{~S}$ ohledem na terminologii a definice pojmů, anglické broadside ballads definici chapbooks spíš neodpovídají (jiná podoba tisku), zatímco české kramářské písně jednoznačně ano. Proto je česká dvojice termínů kramářský tisk - kramářská píseñ vhodná a lze ji vnímat ve vztahu hyperonymum - hyponymum.

${ }^{28}$ Srov. koncept „selského náboženstvi““ Miroslava Moudrého (MOUDRÝ 1942, s. 47-55).

${ }^{29}$ Poutní kultura bývá mimochodem vnímána jako jeden z předpokladů úspěchu rekatolizace v českých zemích (LOUTHAN 2011, s. 236).

${ }^{30}$ MALURA - IVÁNEK 2019, zejména s. 57-62, srov. také katalogovou část. Na př́ikladu poutového zboží shrnula kramáŕské tisky v minulosti HOLUBOVÁ 2003.

${ }^{31}$ Zejm. studie o žánrech barokních náboženských písní (IVÁNEK 2010), kde však bylo přednostně aplikováno na materiál písní o svatých.
} 


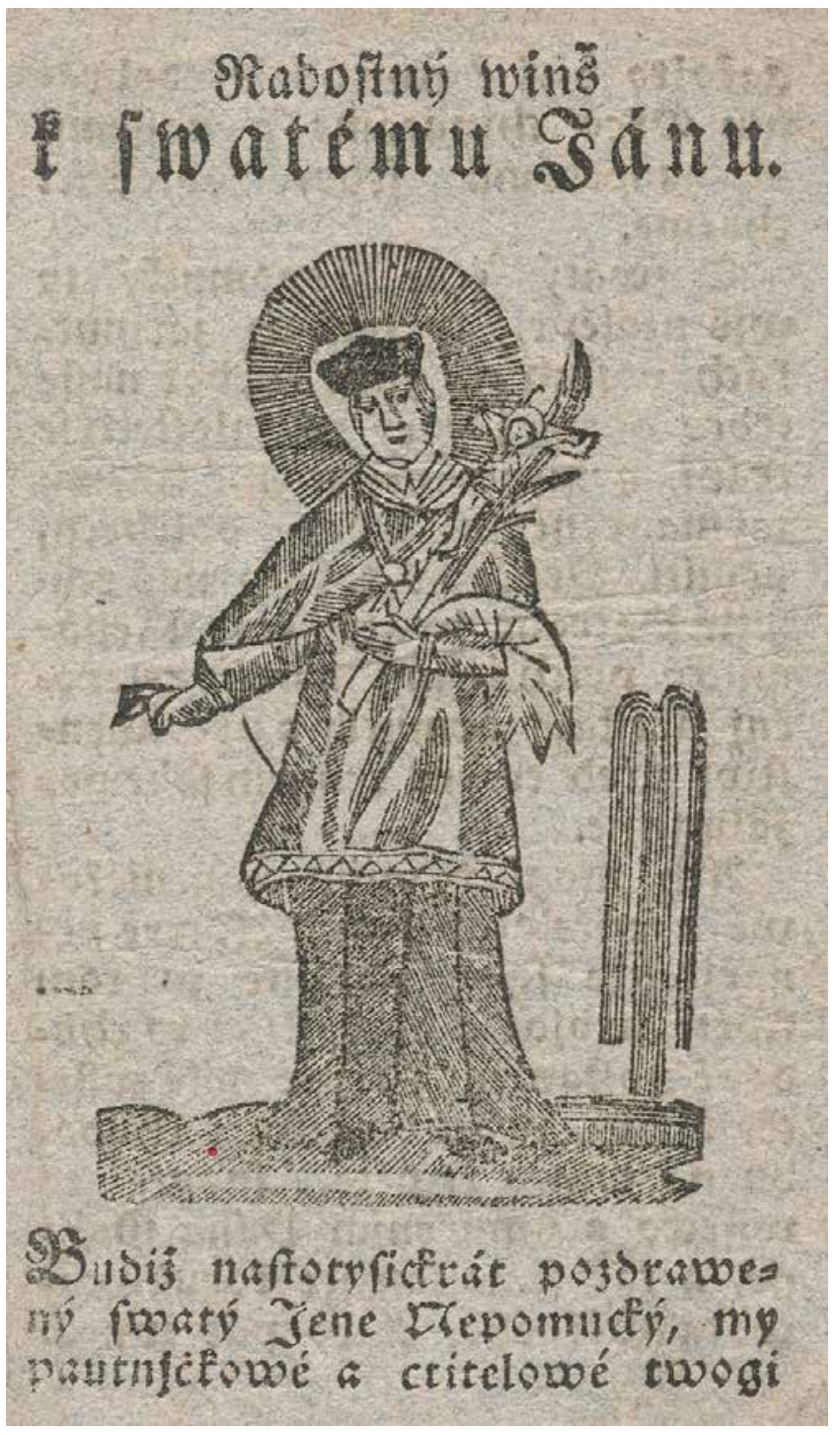

Obr. 1. Titulní strana modlitby k sv. Janu Nepomuckému. Radostný vinš k svatému Jánu, s. I., počátek 19. století? (soukromá sbírka).

tematiku zastupují především různé typy modliteb, svaté obrázky a rozličné pověrečné tisky. ${ }^{32}$ Ke světským kramářským tiskům lze řadit tzv. popisy, snáře, herbáre, horoskopy, testamenty, proroctví, osvětové, kritické a památeční tisky, hry, prání, návody a naučení i parodie těchto žánrů. Hraniční materiál (dle chápání šiře pojmu kramářský tisk) představují další populární tisky, které bychom jako kramářské mohli vnímat $\mathrm{v}$ př́padě jejich kratšího rozsahu. Jsou jimi knížky lidového čtení, praktické kalendáre a opět tisky související s populární (lidovou) zbožností, zejm. modlitební knížky, poutní př́ručky a zpěvníky (kancionálky).

Modlitby zaujímají $\mathrm{v}$ objemu produkce čestné místo a představují samy poměrně pestrou skupinu. Mohou tvořit také jakýsi dodatek písňových tisků, nejčastěji jako prítisk, ${ }^{33}$ nebo př́mo vyústění písně, která k pronesení dané modlitby směřuje. Situace však může být i obrácená. Např. tisk s názvem Modlitba k Blahoslavené Panně Marii Frýdecké obsahuje nejprve tři poutnické modlitby, ale po nich následují dvě mariánské písně. ${ }^{34}$ Titul tisku však o jejich př́tomnosti neinformuje, což může činit potíže při katalogizaci a následném vyhledávání (kramářské písně se katalogizují především dle incipitů, které jsou základním rozlišovacím znakem textů; u modliteb není způsob katalogizace jednotný).

Běžnější jsou samostatně tištěné modlitby, které mají řadu podtypů. Základní podoba představuje osmerkový dvojlist nebo čtyřlist $\mathrm{s}$ úvodním obrázkem a následující modlitbou. Slovo „modlitba“ však nemusí v názvu tisku vůbec figurovat, pokud text slouží ke konkrétnímu zbožnému úkonu v rámci poutní či individuální pobožnosti. Nacházíme tituly jako Pozdravení, Přivitání, Vinš nebo Přání, Vzdechnutí, Loučení, v němčině hojně také Erinnerung (Vzpomínka či Památka), Geisteserhebung (Povznesení duše), Opferung (Obětování), nebo na př́kladu konkrétního tisku: Marianischer Einzug nebst beygefügten Valedictionsund Urlaubs-Seufzern (Mariánský prííchod [rozuměj privitáni] s připojeným vzdycháním pro loučení a odcházení).

Existují také speciální typy modliteb jako např. Patnáct tajemstvi Krista coby lístková modlitba, která se stř́hala na samostatné karty, modlitba $\mathrm{v}$ podobě rébusu, kde některá slova zastupují obrázky (tzv. Rebusild), či rozjímání Kristova utrpení pro jednotlivé dny měsíce (tabulka o 31 položkách). Brožury s pobožností hodinek se objevují častěji od poloviny 19. století jako poutnický tisk (dříve byly spojeny s náboženskými bratrstvy a bývaly součástí rozsáhlejších knižních publikací; mívají rovněž připojeny písně). Sešitový charakter měly modlitební publikace Hvězdový věneček aneb dvanáctero svátků výročních Panny Marie či regionálně diferencované Mariánské zahrádky (v německé mutaci Marianischer Lustgarten), které přinášejí rytiny milostných obrazů s modlitbou na protilehlé straně. K modlitebním tiskům lze řadit též samostatná vydání litanií a žalmů (někdy jen oboustranně potištěný jednolist).

Problematické může být stanovení hranice mezi tiskem modlitby a svatým obrázkem (Andachtsbildchen). Tato způsobem výroby, velikostí i zastoupením textu pestrá skupina devocionálií vznikla již v době středověku, avšak právě tisk způsobil rostoucí popularitu, a tím i rozšíření svatých obrázků. Vrcholu dosáhla jejich masová výroba v 19. století. ${ }^{35}$ Svaté obrázky bývají vzhledem $\mathrm{k}$ různým materiálům a technikám zpracování vnímány coby samostatná skupina, oddělená od ostatních kramářských tisků (srov. KAFKA 2009, s. 191). Protože hranice mezi primárně obrazovou devocionálií (jak definuje svaté obrázky např. Kafka) a devocionálií s primárně textovou složkou bývá nejasná (Kafka

\footnotetext{
${ }^{32}$ Ačkoli na tomto místě sledujeme pouze kramářské tisky (tedy tiššné zboží šířené kramáři), všechny zmíněné skupiny jsou z etnografického hlediska řazeny také pod devocionálie, tedy předměty, které plnily v rámci lidového kolektivu ochrannou, léčivou, kultovní a upomínkovou funkci. Termín devocionálie zahrnuje nejen tištěné zboži (které tvoří jeho podstatnou část), ale i předměty vyráběné prakticky ze všech dostupných materiálů, a to obchodníky, ale i v klášterních dílnách či samotnými uživateli podomácku (srov. DVOŘÁKOVÁ 2007).

${ }^{33}$ Srov. hesla Prritisk a Př́davek v online Encyklopedii knihy Petra Voita, dostupné z: www.encyklopedieknihy.cz

${ }^{34}$ Zemský archiv Opava, Sbírka kramářských tisků, inv. č. 418.

${ }^{35}$ V minulosti tento fenomén zkoumali Adolf Spamer, Karel Procházka, Gustav Gugitz ad. Z novějš́ literatury např. KAFKA 2009, s. 186-196; CHARVÁTOVÁ 2007; LUKAS - PÍŠA - WÖGERBAUER 2017.
} 


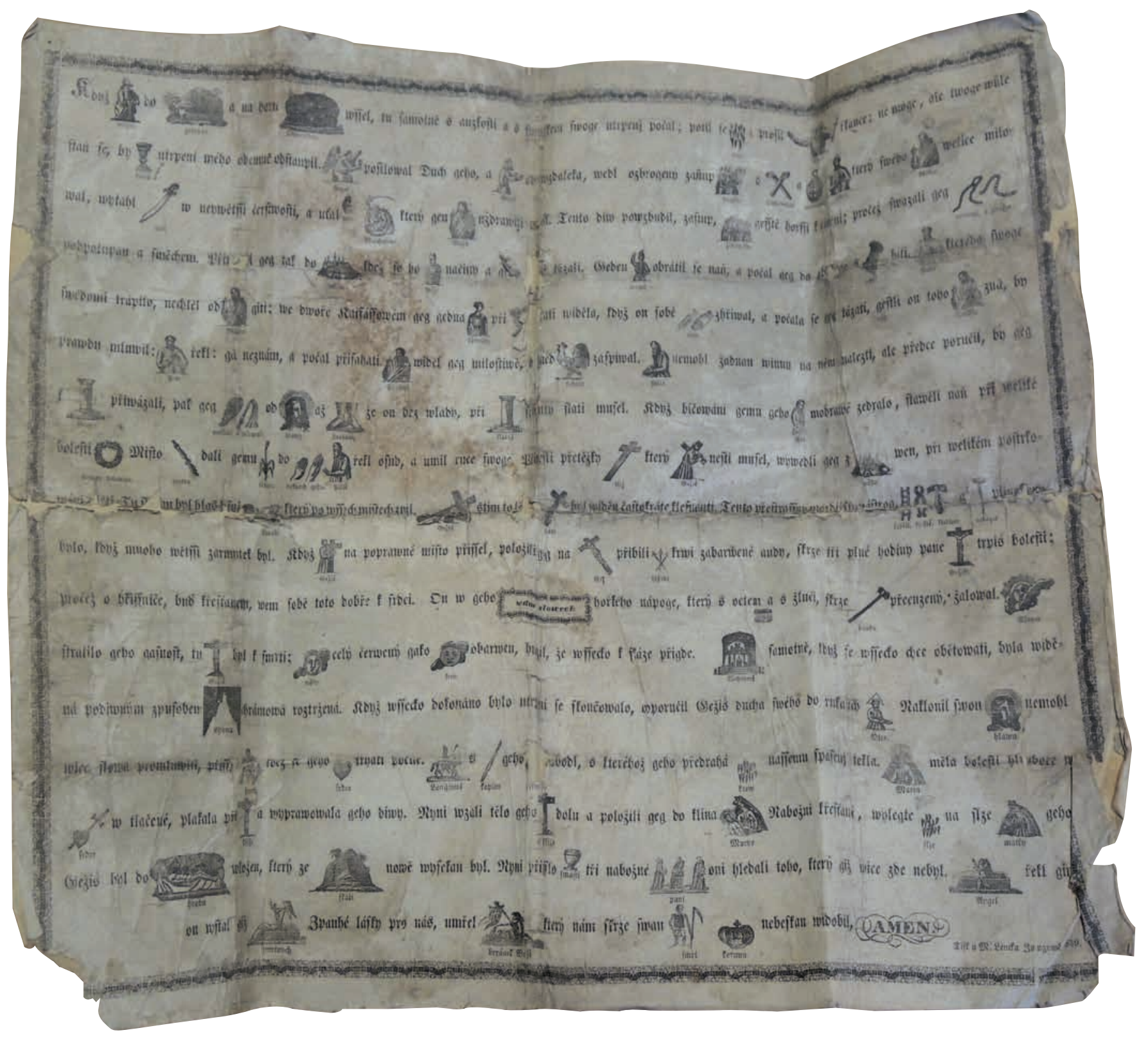

Obr. 2. Modlitba na pašijové téma ve formě rébusu. Znojmo: M. Lenck, 1859 (Muzeum Brněnska, Sbírka Muzea v Ivančicích, IC/233-23).

např. řadí do svatých obrázků i psaníčka, kde však nelze textovou, modlitební složku považovat za druhotnou), dovoluji si chápat i toto kramářské zboží, je-li tištěno, coby kramářský tisk. Ostatně sám Kafka na jiném místě tvrdí: „, S náboženskými kramářrskými modlitbami a písněmi spojuje svaté obrázky řada společných znaků: analogický vícečlánkový proces vzniku a odbytu i podobný okruh výrobců. Jak kramářské tisky, tak svaté obrázky sloužily jako devocionálie (nebo se uživaly pověrečným zpiosobem), bývaly věrícími kupovány na poutích, plnily funkci upominek a byly přinášeny blízkým jako dárky. "36 Je zřejmé, že termíny kramářský tisk, svatý obrázek a devocionálie nelze chápat striktně odděleně, vzájemně se prolínají. V podstatě se liší perspektivou pohledu (způsob prodeje, převažující složka, způsob užití).

Svaté obrázky mohly být převážně obrazovým artefaktem s titulem a krátkým textem vysvětlujícím vyobrazení, a to $v$ rozličných velikostech - od klasické osmerky po foliové tisky, které si věřící kupovali na poutních místech jako kopie milostných obrazů a doma je věšeli na zdi nebo je zasazovali do kaplí a božích muk. Takové využití tištěné kopie milostných obrazů mohlo položit základ novému poutnímu místu. ${ }^{37}$ Rozměrné (vesměs foliové) jednolisty potištěné jednostranně obrazem a většinou pouze krátkým slovním doprovodem nejsou však jen záležitostí kopií milostných

\footnotetext{
${ }^{36}$ KAFKA 2009, s. 199-200.

${ }^{37}$ Srov. př́pady Dubu nad Moravou a Rychnova nad Kněžnou (MALURA - IVÁNEK 2019, s. 249-264).
} 


\section{(5) nat benbito unierer lieben Frau zu Buctmantet

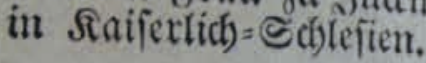

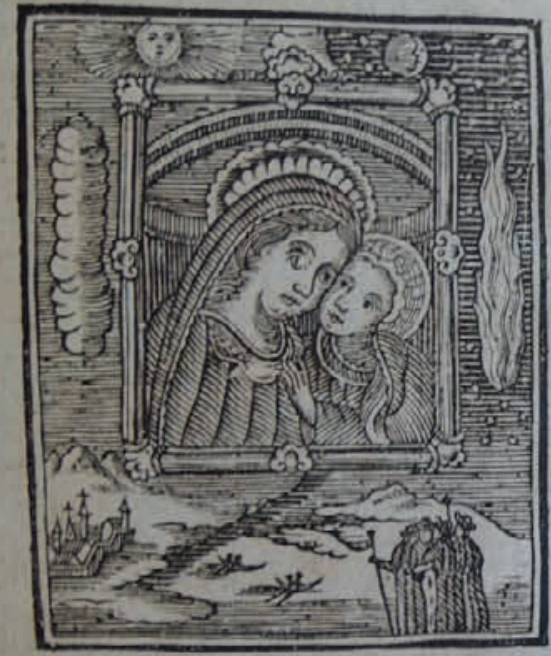

Mit beiner Syilfe fief' uns an, Syutger und 'Beft ftets von uns wenb' 2̧or'm geinb befdjübe uns bebent, 3n Tobesnotly vimu bid unjerer aut.

\section{(s) e b e t.}

Silf, o Maria Silf! but Sclfe=

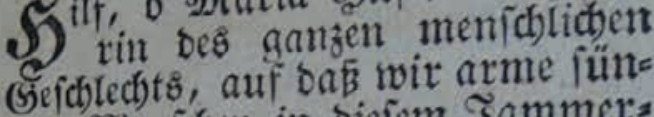
bige Mienichen in biefem Sammer thal bie 3eit unjerer spilgetichaft in seiligfeit und (serechtigteit aljo vor sjott wanbeln, wie es ibm gefällig ift. 2(ber, o s) Raria! obre bie Snabe beines reichen Sobntes vermögen wir nict) beiner Fürbitte, bilf, o Maria Silf! but Selfertn Det ganzen (Ebriftenbeit, bilf uns von ficht= und unjichtbaten Feinben Der Seele und bes ganzen Leibes, mit benen wir genugfom zu fämpfen baben. SD Miaria! obne bie Macht (Sottes unterliegen roir, bu Berfniricherin ber alten Schlange, auf bas nidit überwunben werben; biff, D Maria 5ilf! 2imen.

Obr. 3. Dvojstrana s vyobrazením Panny Marie Pomocné (Maria Hilf) u Zlatých Hor s př́slušnou modlitbou z německé varianty „mariánské" zahrádky. Marianischer Lustgarten, s. I., 1827 (Knihovna Národního muzea, sbírka B. Přibila, karton Modlitby, Náboženské tisky, nezpracováno).

obrazů. S tímto typem, který postrádá jednoznačný český ekvivalent, se setkáváme také v oblasti světských tisků. Němci jej nazývají Bilderbogen („obrazový arch“). ${ }^{38} \mathrm{~V}$ ruské kultuře je na těchto obrazových tiscích zv. lubok postavena většina „kramářské“ literatury. ${ }^{39}$

Naproti velkoformátovému tisku se už ve starší době vyvinul dnes běžný typ svatého obrázku představující drobný jednolist potištěný z jedné strany obrazem, ze druhé krátkou modlitbou. Ta může mít vlastní titul, jako by šlo o modlitební tisk. Objevují se i jednostranně potištěné dvojlisty, respektive přehnuté jednolisty. Takové tisky můžeme vnímat jako variantu svatého obrázku, ale také jako nalepovací (ochrannou) modlitbu (viz níže). Adolf Spamer nerozlišuje mezi převážně obrazovými a textově-obrazovými drobnými tisky (Gebetszettel, „modlitební lístek“) a všechny nazývá kleine Andachtsbilder. ${ }^{40}$ Jan Royt navrhuje nazývat tyto projevy „drobná devoční grafika“" ${ }^{41}$ ovšem termín svatý obrázek je již v českém prostředí zavedený.

Ne každý tištěný svatý obrázek byl však kramářským zbožím. Ve sbírkách najdeme rovněž tisky s náročnějšími rytinami, u nichž předpokládáme šlechtického či církevního zadavatele. Takové obrázky zpravidla nebyly předmětem kramářského obchodu, ale rozdávaly se. ${ }^{42}$ Je to i případ tzv. měsíčních obrázků (osmerkové, oboustranně potištěné jednolisty s vyobrazením světce, citátem, označením ctnosti a modlitbou). Propagovali je jezuité a sloužily především k volbě měsíčního patrona (Monatspatron) losováním $\mathrm{v}$ rámci náboženských bratrstev. ${ }^{43}$

Jako svaté obrázky bývají označovány i modlitby určené původně k nalepení na víka truhel, dveře skř́ně a jiná místa v domácnosti, kde s tiskem přicházeli lidé často do kontaktu, mohli nad ním rozjímat, modlit se z něj a zároveň věřili v jeho

\footnotetext{
${ }^{38}$ Srov. heslo Bilderbogen v online Encyklopedii knihy Petra Voita, dostupné z: www.encyklopedieknihy.cz

${ }^{39}$ CHUCHVAHA 2011.

40 SPAMER 1930.

${ }^{41}$ ROYT 2011, s. 331.

${ }^{42}$ ROYT 2011, s. 340.

${ }^{43}$ SPAMER 1930, s. 171-172; ROYT 2011, s. 342.
} 


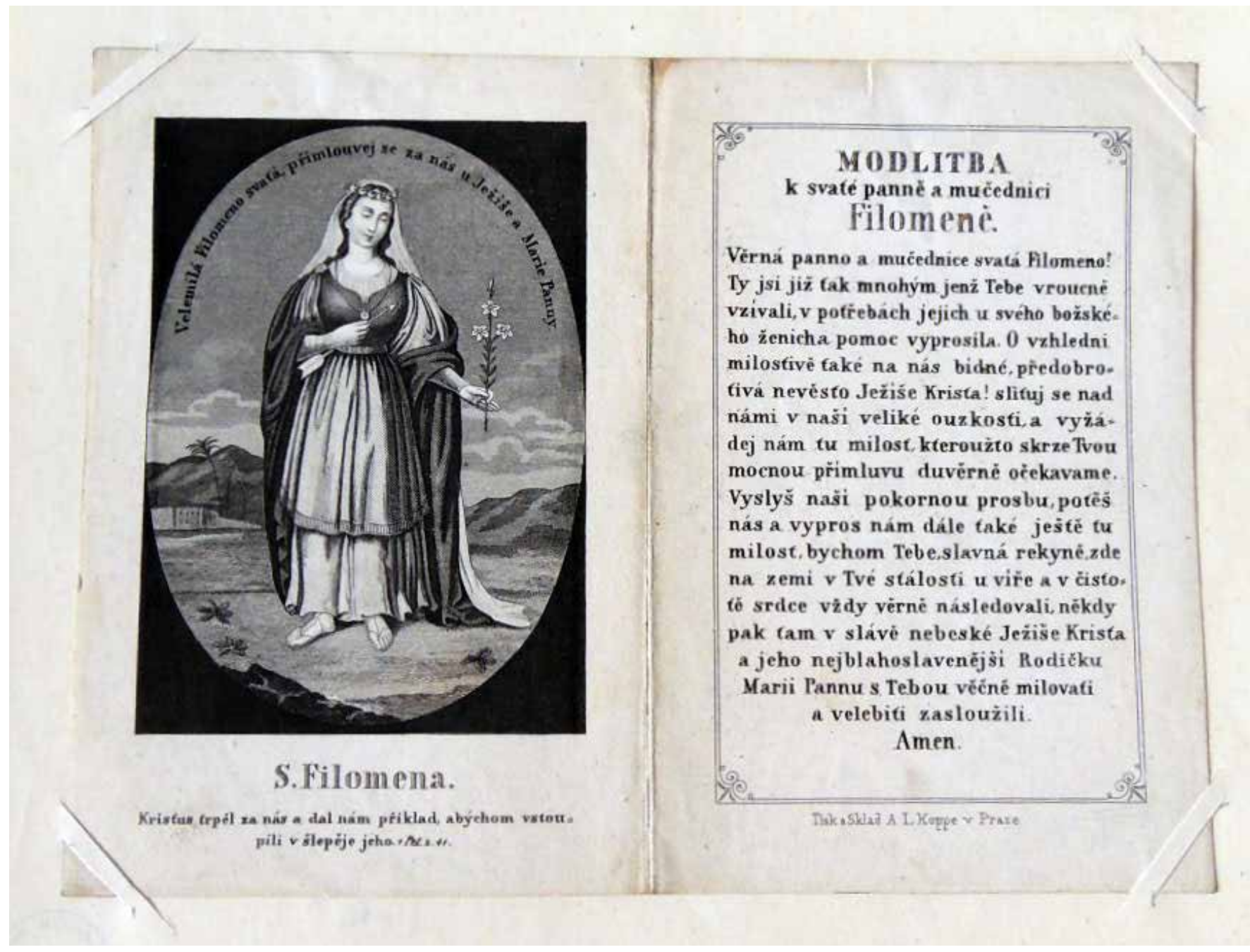

Obr. 4. Svatý obrázek s módní světicí 19. století sv. Filoménou. Praha: A. L. Koppe, přelom 19. a 20. století (Knihovna Národního muzea, Modlitby 2008).

ochrannou moc (apotropaion). Nemuselo však jít o pověrečné tisky, třebaže jejich užití jim domněle magickou moc dávalo. Nejčastější jsou jednostranně potištěné jednolisty podélné orientace v trrísloupcovém rozvržení, kde obrázek tvoří součást prostředního sloupce. Vzhledem $\mathrm{k}$ přidané dekorativní funkci bývaly obrázky či celé tyto tisky kolorovány. Jelikož se dochovaly především nenalepené exempláře, které byly nadvakrát přehnuty a vloženy do modlitební knihy, ř́ká se jim též skládací obrázky (tak činí např. Procházka).

Ochrannou funkcí jsou tyto modlitby blízké pověrečným tiskům, které jsou z hlediska oficiální věrouky většinou závadné. Zejména venkované věřili v magickou moc předmětů a slov. ${ }^{44}$ Tomu vycházeli vstříc tiskaři, kteří vydávali nepovolené modlitby, jež měly chránit majitele či statek. K církví tolerovaným ochranným prostředkům patřily dotýkané tisky (svaté obrázky tištěné na papír či látku nebo prosté lístky s formulí dokládající, že byly dotčeny o relikvie, hrob světce nebo olej z hrobu vytékající, někdy i s pečetí). Ty mohly být spolu s dalšími ochrannými materiály (bylinami, korály, perlami apod.) vkládány do škapulírư či amuletů (např. novorozeneckých), jež měly být nošeny na těle. ${ }^{45}$ I ty měly svou základní tištěnou složku (obrázky s Pannou Marií, patrony, ochrannými kříži, ranami Krista, obvykle v kompozici devíti plošek). Četným pověrečným tiskủm byla v minulosti věnována hojná pozornost (Jan Tykač, Čeněk Zíbrt, K. Paul aj.). ${ }^{46}$ Některé $z$ nich se lepily či vyvěšovaly v domě (tzv. domovní požehnání, jež mohlo být až plakátového rozměru). Obdobným způsobem mohly být užívány i tzv. svaté délky, z nichž nejrozšířenější byla Délka Krista, která mohla mít různé podoby: Patrně nejstarším typem jsou obrázky „skutečné velikosti“ Kristovy rány s křížkem, jehož zvětšení v uvedeném násobku dávalo „skutečnou délku/výšku“ Kristova těla. Stanovená délka (zhruba $1,70 \mathrm{~m}$ ) mohla být převedena např. na dřevěnou lat', která byla zabudovávána do krovu, aby chránila dům před bleskem. Najdeme však také modlitbami potištěné papírové pásy, jejichž délka dává pověrečnou výšku Krista. ${ }^{47}$ Pozdější tisky Kristovy délky jsou jen sešitkem modliteb bez znázornění velikosti. $\mathrm{K}$ dalším

\footnotetext{
${ }^{44}$ Srov. MOUDRÝ 1942

${ }^{45}$ KAFKA $2007 \mathrm{a}$.

${ }^{46}$ Souhrnněji PETRTYL 1959 a VEČERKOVÁ 1999.

${ }^{47}$ Rozšířené byly také délky mariánské, ale existovaly i další (srov. KAFKA 2007b; HOLUBOVÁ 2003, s. 563).
} 


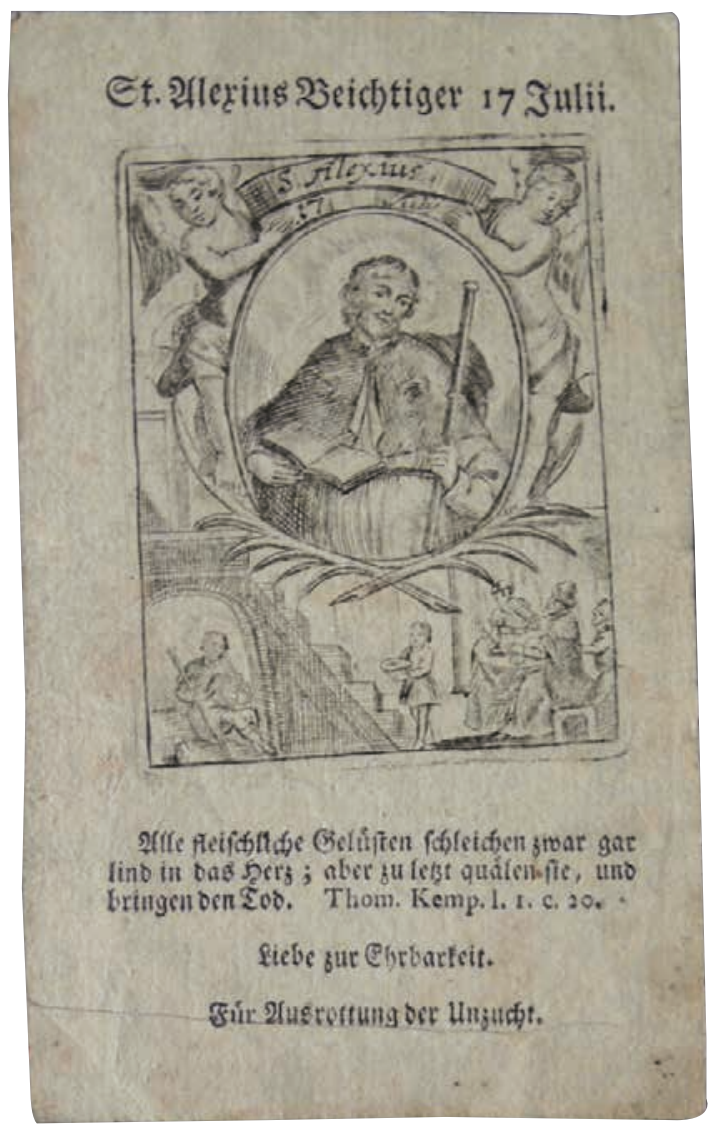

(5) be beifige 2flexins, Eupbemiani cincs ro: 5) betige Rathsherrm Eobn, ift oic crite

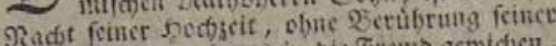
Sinut aus beit sous in ste fremo gerviden.

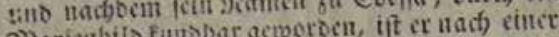

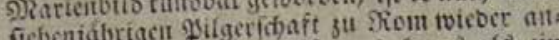

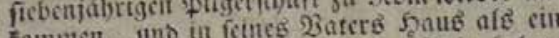
fommen, unb tir fetres batre se Yabe boheranner Bettler, anbere fietenzeben Gabe boter bergt morben. Shat bie 20elt mit etine netrent, Siun te berrogen, inoem or unbefaunt geblicbert,

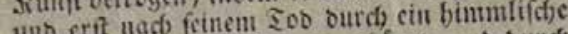

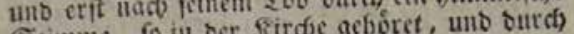
Stimme, fo til bor sirta) gebort, fein eigene Seantofdrift ertant worbent. Sit unter bem 25abfe Jntocentio Dem Erfien un bes unter ben tacil frirche mit bodster Ebr getras

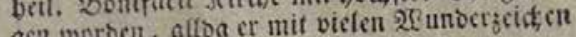
getcuctitet bat. Ex Brev, \& Mart Rom.

Giebet.

Bott! bee bu uns surd́ bas jábrliche Fecit

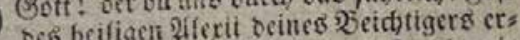
beb beifigen alferit beites beidytigers ces

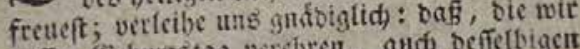
freteit, seburtatag verehren, aud) beffelbigen Serten Sebutstag octolgen, Durd) Ebrifum unfern feerth, \&men.

Obr. 5a a 5b. Měsíční obrázek sv. Alexia (rub a líc), který vzhledem k funkci v náboženských bratrstvech nelze považovat za komerční, tudíz kramářský tisk (Knihovna Národního muzea, Modlitby 4362).

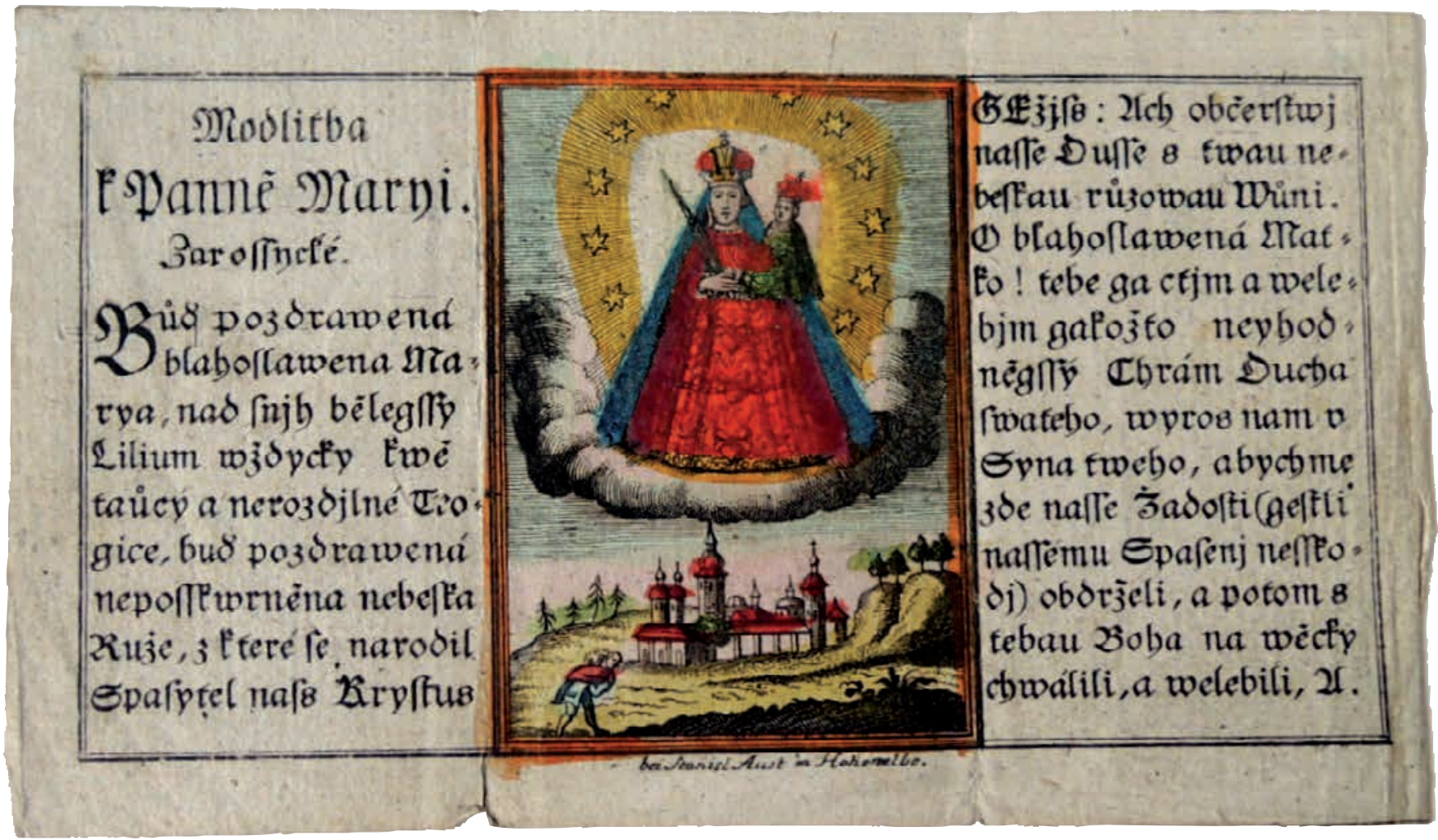

Obr. 6. Trojdílné nalepovací/skládací obrázky s modlitbou byly často dodatečně kolorovány. Modlitba k Panně Marii Zarošické. Vrchlabí: Stanislav Aust, 19. století (Knihovna Národního muzea, Modlitby 1692). 


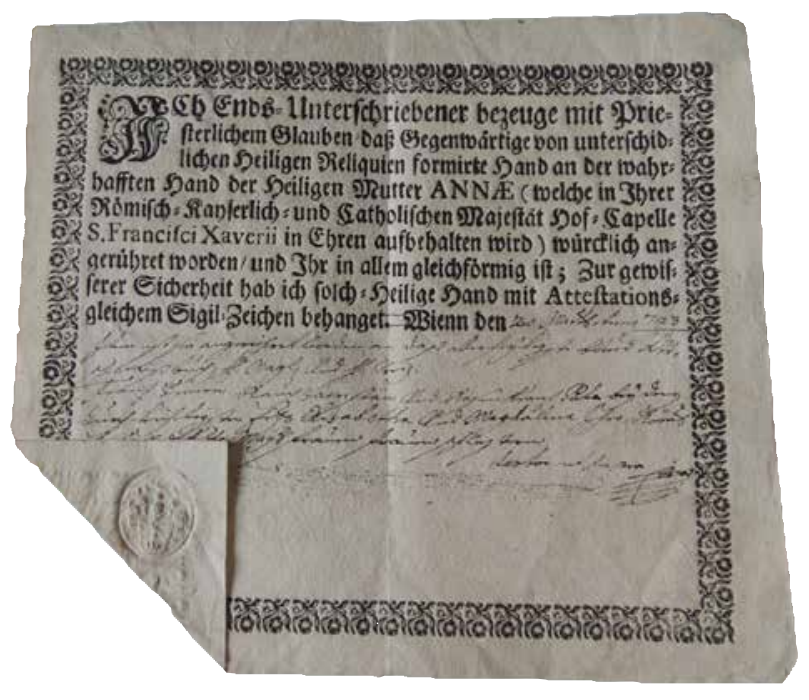

Obr. 7. Potvrzení o dotčení rukou sv. Anny chované v dvorské kapli sv. Františka Xaverského ve Vídni s pečetí a připsaným potvrzením z roku 1723 (Knihovna Národního muzea, Modlitby 4502).

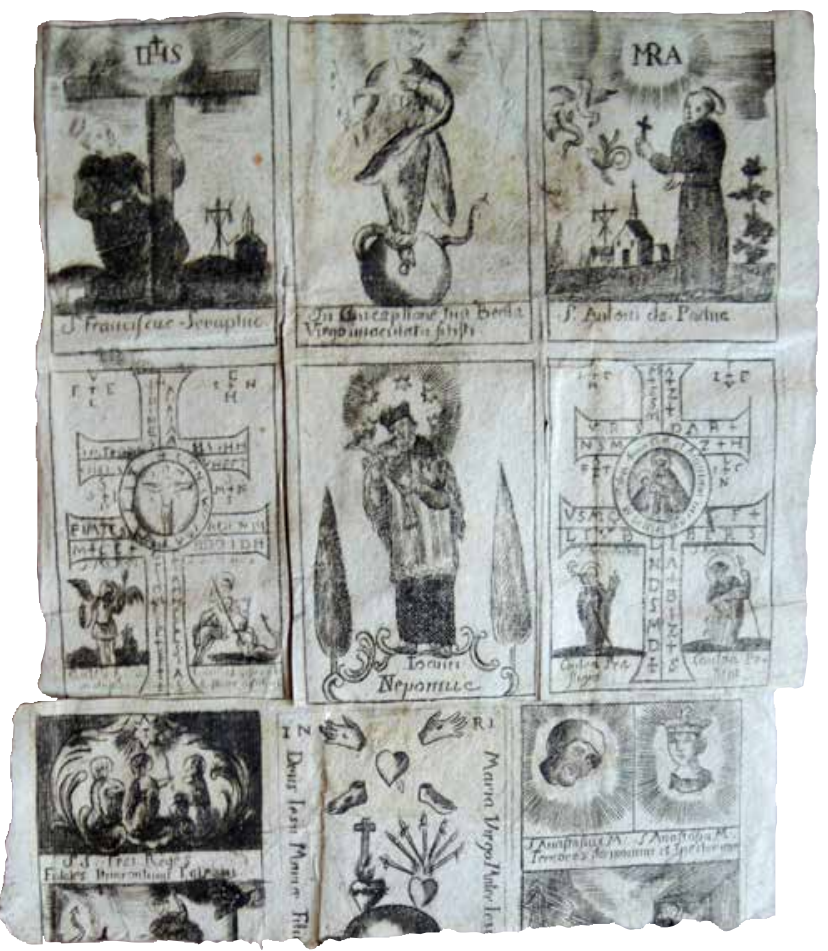

Obr. 8. Př́klad obrázkového tisku svatých symbolů a osob, který byl vkládán do novorozeneckého amuletu, chebské provenience (Knihovna Národního muzea, sbírka B. Přibila, nezpracováno).

běžným pověrečným tiskům patř́ List poslaný z nebe (tisk slibující ochranu těm, kteří ho šiří, a zatracení těm, kteří tak neučiní), Sedm zámků (mají vysvobodit duše z očistce), ${ }^{48}$ Modlitba ke sv. Koroně (za získání bohatství), Žalář Pána Ježiše Krista (modlitba chránící dům), Zachariášiov křiž či požehnání (proti moru) ad. Mezi pověrečné tisky řadíme i fenomén polykacích obrázků (Schluckbilder), které byly uživány vnitřně jako profylaktický i léčebný prostředek.

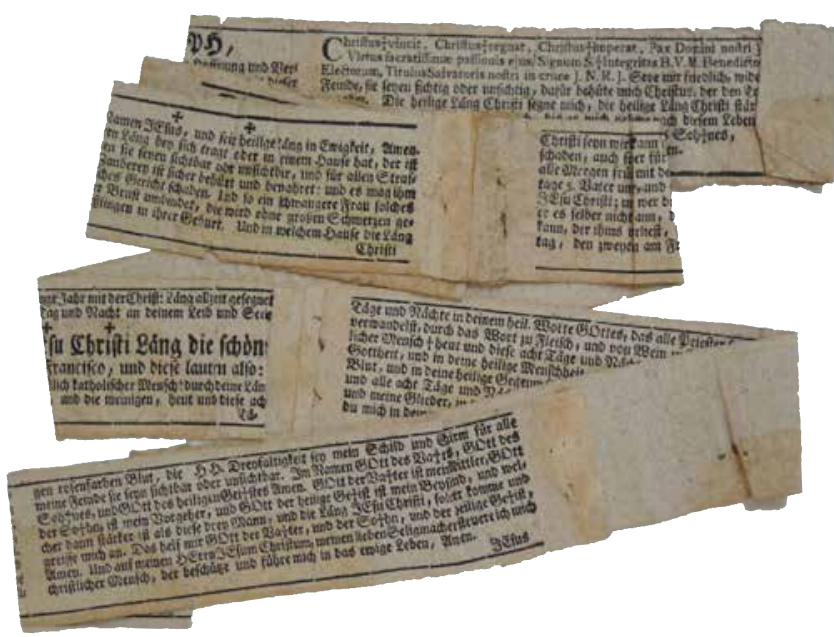

Obr. 9. Délka Krista v podobě 1,7 m dlouhého pásu potištěného modlitbami (Knihovna Národního muzea, sbírka B. Přibila, nezpracováno).

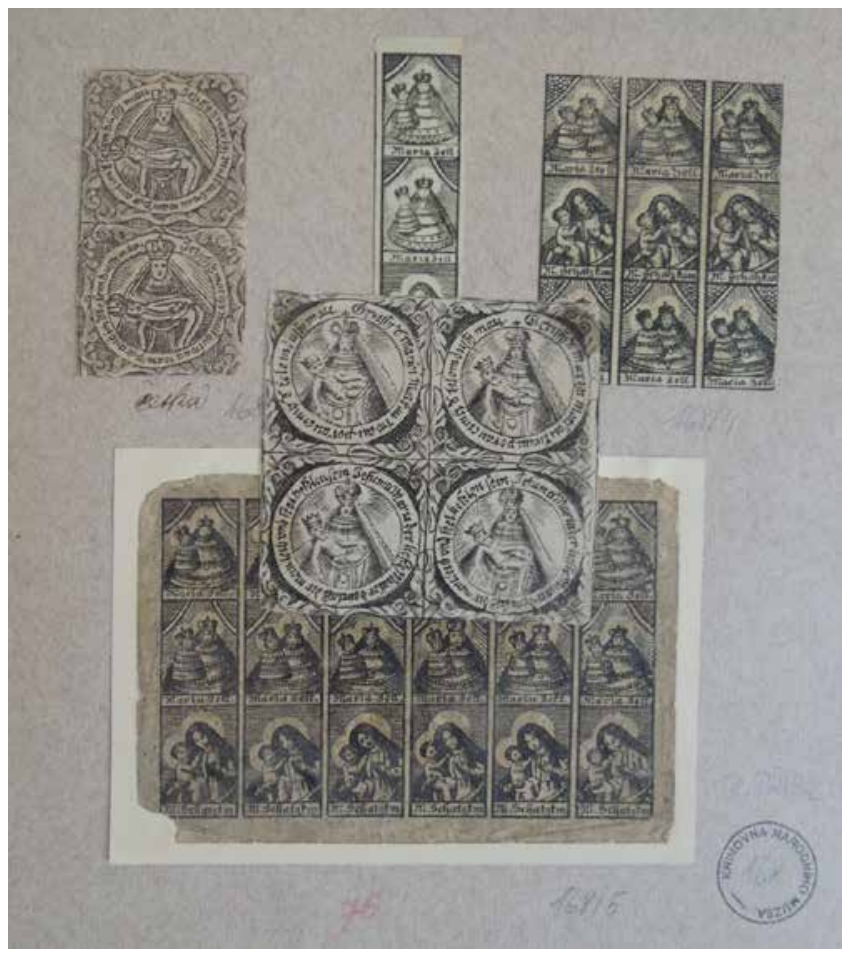

Obr. 10. Různé typy polykacích obrázků s vyobrazením Piety (s českými nápisy) a Panny Marie Cellenské i obrazu Panny Marie z pokladnice $v$ Mariazell (Knihovna Národního muzea, sbírka B. Přibila, nezpracováno).

Pověrčivost a víra $\mathrm{v}$ nadpřirozeno se ostatně odrážely i v oblasti světských kramářských tisků, kde narážíme na různá proroctví, některá aktuální (vztahující se např. $\mathrm{k}$ dobovým válečným konfliktům), jiná vydávaná opakovaně od 16. století až do konce 19. století (zvlášt' rozšířené bylo zejména Proroctví slepého mládence, které měl již ve 14. století sdělit Karlu IV.), a také snáře, jež měly zprvu

\footnotetext{
${ }^{48}$ Modlitba Sedm zámků paradoxně vycházela rovněž v populární modlitební knize Velká štěpná zahrada od Martina z Kochemu (srov. KVAPIL 2001, s. 18). Jeho knihy však mívaly opakovaně potíže s nevhodnými pasážemi (TAMTÉŽ, s. 52-58).
} 
pomoci ve výkladu snů, které v lidové víře naznačovaly budoucnost, později získaly navíc charakter praktického rádce, jaká čísla sázet v loterii. Samostatně mohly vycházet i horoskopy, které bývaly zpravidla součástí kalendářů (viz níže).

Zvláštním typem na hranici náboženských a světských kramářských tisků jsou psaníčka (Klappbriefe), což byly listy oboustranně potištěné obrázky a rozjímavými texty či modlitbami, které se skládaly po vzoru dopisu a nosily se často jako dárek z pouti. Vedle poutních psaníček se v 19. století objevují také psaníčka s tematikou memento mori, začínající připomínkou prvního hříchu a uvnitř zobrazující módně vystrojený pár, ze kterého se po úplném otevření stanou kostlivci. Spamer uvádí, že tento typ, v německých oblastech známý od 16 . století, mohl být součástí novoročních lístků (Neujahrsgedenken). ${ }^{49}$

Ze světských kramářských tisků věnujme bližší pozornost tiskům s prozaickými texty, které bavily i vychovávaly (př́padně informovaly, i když zpravodajská funkce kramářského materiálu byla $\mathrm{v}$ minulosti spíš přeceňována). ${ }^{50}$ Fenomén knížek lidového čtení (v dobové terminologii nejčastěji historie a kroniky, $\mathrm{z}$ dnešního pohledu jde vesměs o povídky) je starý jako sám knihtisk. Zvlášs’ populární se v raně novověké Evropě staly krátké př́iběhy nabalující se na postavy vtipných hrdinů, jimiž byli Fortunatus, Ezop a Ejlenšpigel, ale také trojice povídek o osudem zkoušených ženách - Meluzině, Mageloně a Jenovéfě..$^{51}$ Setrvačnost těchto (často velmi starých - středověkých, či dokonce starověkých) látek byla nesmírná. Zvlášt' oblíbené př́íběhy, jež

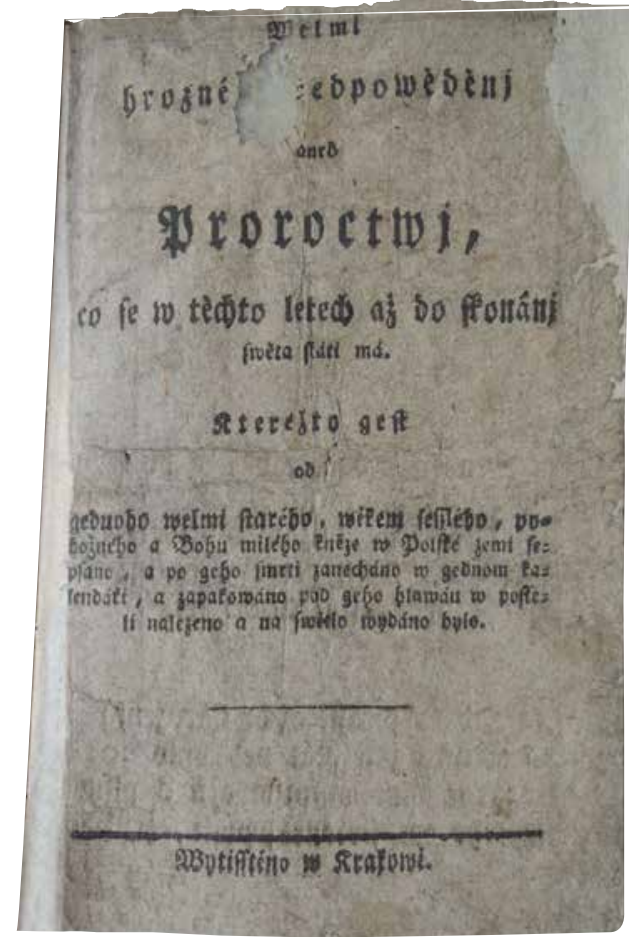

Obr. 11. Tisk Velmi hrozné predpovědění aneb Proroctví, co se v těchto letech až do skonání světa státi má... se tváŕí jako vize zapsaná starým polským knězem před jeho smrtí. Krakovské impresum bez datace je nutno brát vzhledem $\mathrm{k}$ obsahu s rezervou, asi pred rokem 1820 (Knihovna Národního muzea, Obrození, 5 D 49).

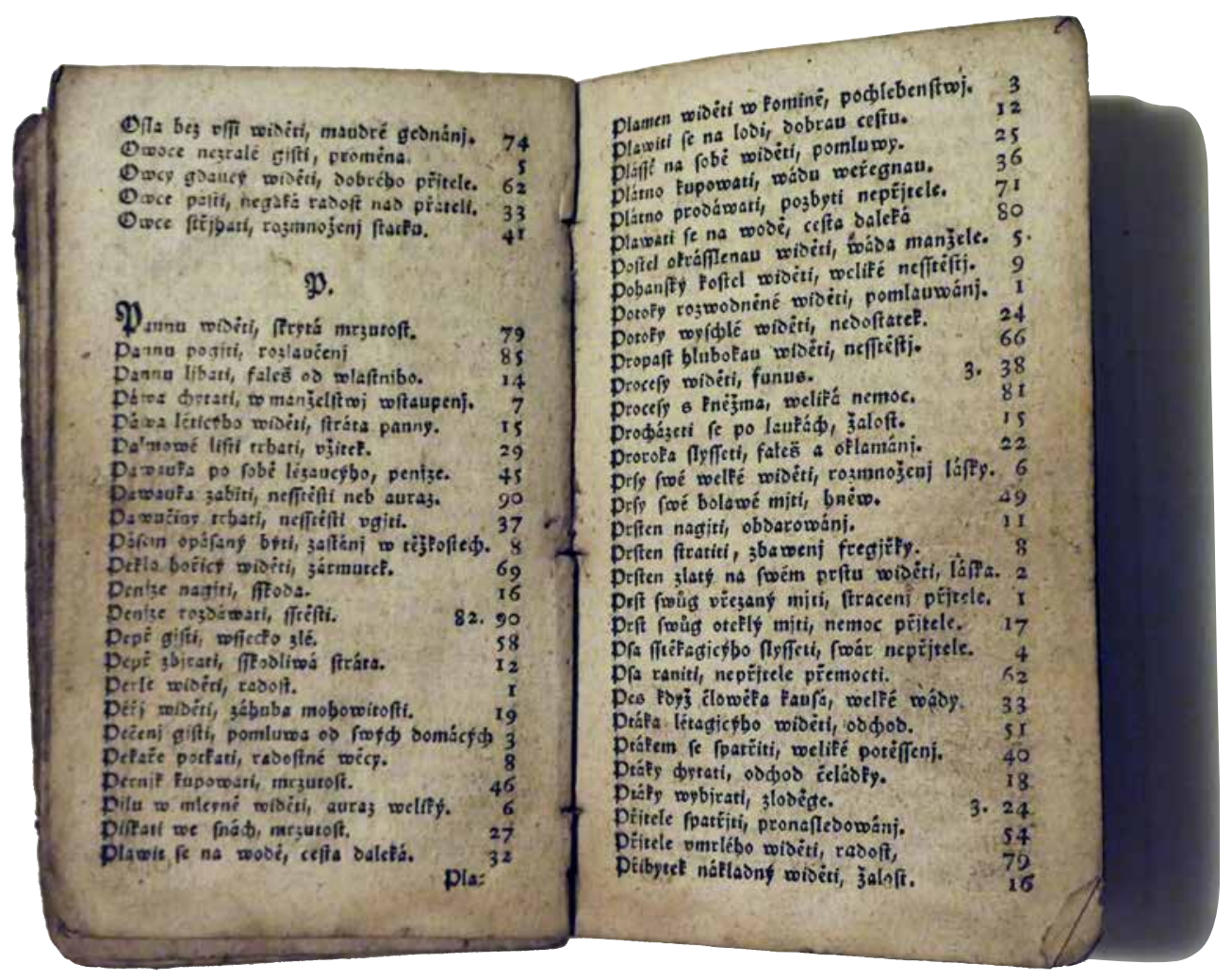

Obr. 12. Dvojstrana ze snáře s krátkým výkladem snů a čísly do loterie. Krátké vejklady o důmělém zdání snův, skrze kteréjedenkaždý, bud'sám sobě, aneb jinému vyložiti může, jakož i numera, které dle vyznamenání snů do loterie se sázeti můžou, s. l., konec 18. století (soukromá sbírka).

\footnotetext{
${ }^{49}$ SPAMER 1930, s. 165.

${ }^{50}$ Ke vztahu informativní vs. zábavné funkce tohoto čtiva srov. např. MALURA - IVÁNEK 2019, s. 311, v anglickém prostředí NEWCOMB 2011 , s. 482.

${ }^{51}$ České verze s komentářem k textům i obecně ke knížkám lidového čtení vydal KOLÁR 2000, 2004.
} 


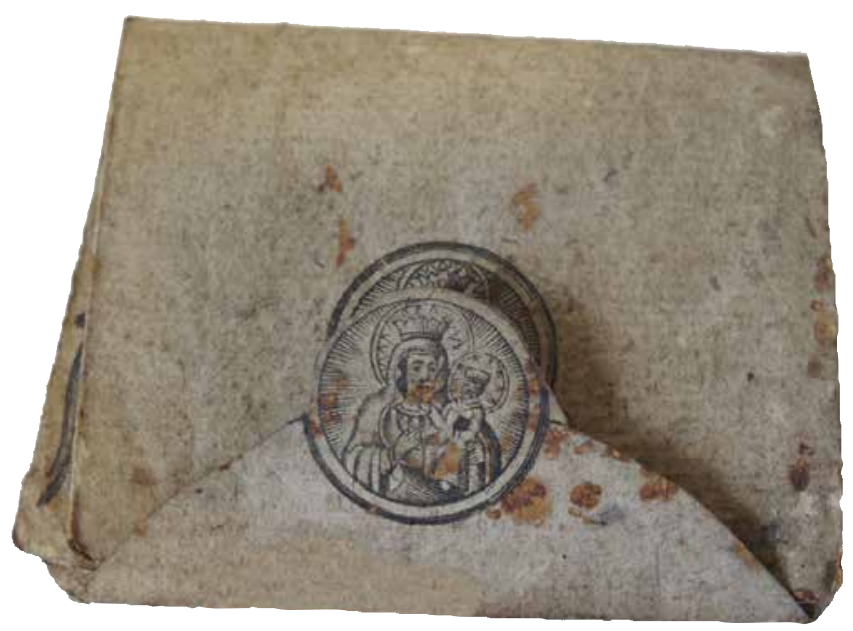

Obr. 13. Složené poutní psaníčko s obrázkem Panny Marie Čenstochovské (Knihovna Národního muzea, Modlitby 1209).

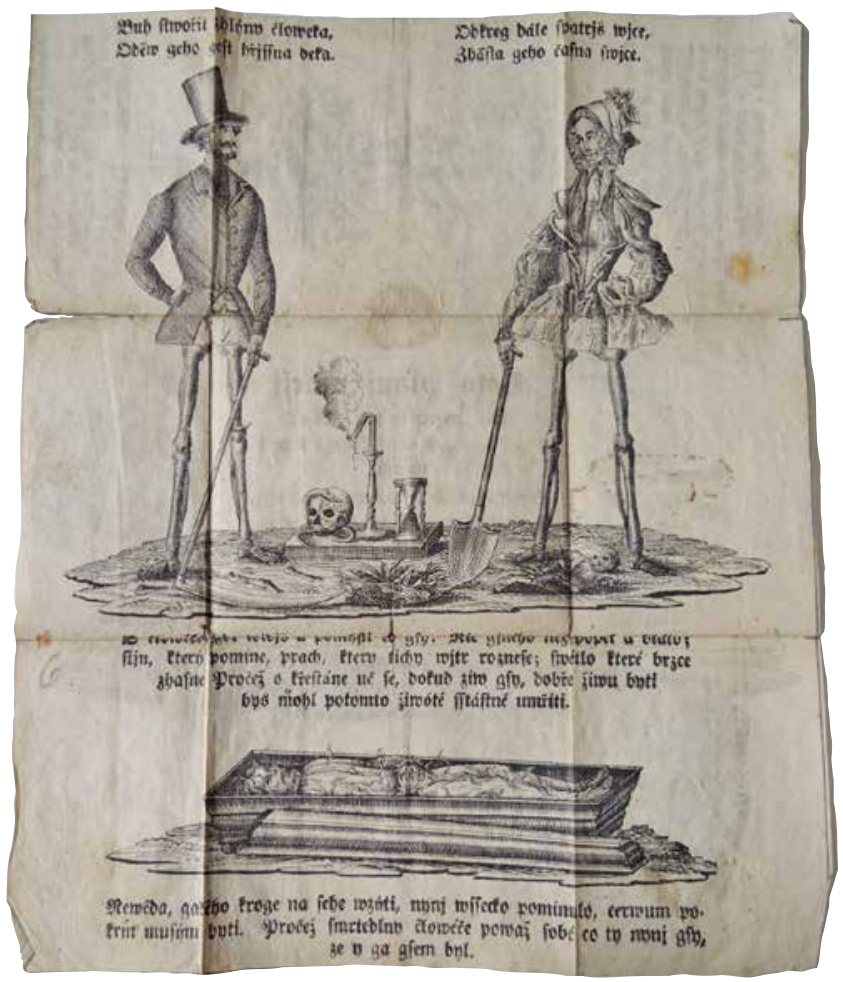

Obr. 14. Rozložené psaníčko s tematikou Memento mori (Knihovna Národního muzea, Modlitby 4666).

známe už ve vydáních ze 16 . století, kdy byla tato literatura populárním čtivem měšt’anů, vycházely až do konce
19. století, kdy pronikly až do nejnižších vrstev venkovského obyvatelstva. Frekvence vydávání těchto tisků roste spolu s gramotností společnosti od druhé poloviny 18. století, zejména pak na přelomu 18. a 19. století. ${ }^{52}$ Také obrozenci si byli vědomi značné obliby knížek lidového čtení mezi městským i venkovským obyvatelstvem, a tak se pokoušeli nahradit staré (dle nich nevhodné) čtivo novým, které by vychovávalo k národnímu cítění, nové morálce a také „správné češtině“ .53

Jak jsem již výše naznačil, knížky lidového čtení jsou z pohledu kramářské produkce hraničním materiálem. Už sám zaužívaný termín naznačuje rozměrnější díla. I přes sešitový charakter tisků (pevnou vazbu většinou neměly) se svým rozsahem blížily více knize. Např. edice zmiňované Meluzíny se rozsahem pohybovaly většinou mezi 60 a 80 listy (tj. 120-160 stran) osmerkového formátu, takže na výrobu jedné knihy bylo využito až 10 archů papíru. To je rozsah značně přesahující tradiční chápání kramářského tisku, třebaže se lze domnívat, že i tento tiskařský materiál byl šířen především trhovým a podomním prodejem. Vyšší cena (která odpovídala množství papíru a náročnější sazbě) však jistě způsobila, že kompletní překlad Meluzíny si zřejmě nemohl (na rozdíl od kramářské písně) dovolit každý. ${ }^{54}$

Jedním ze způsobů, jak tyto populární příběhy vydat s nízkými náklady a rozšířit je mezi široké vrstvy obyvatelstva, byl převod prózy do veršů, tedy vznik dlouhé vyprávěcí písně. Velmi populární se stala např. píseň o barokní hrdince Jenovéfě, která vyšla od poloviny 18 . století mnohokrát. ${ }^{55}$ Ta se již vměstnala na osm listů šestnácterkového formátu, takže z jednoho archu mohly vzniknout hned dva exempláře kramářské písně. Navíc $\mathrm{v}$ závěru písně čtenář našel rovněž „reklamu“ odkazující na obsáhlejší prozaickou verzi, která vycházela paralelně. ${ }^{56}$

Další cestou, jak zprostředkovat čtenářům světské, ale i nábožné př́iběhy z knížek lidového čtení, bylo vydávání příběhu na pokračování v kalendář́ch. Kalendáře (tradičně nazývané též minuce, pranostiky či almanachy) představují rovněž hraniční médium. Většina z nich měla knižní charakter, třebaže šlo o velmi populární, a tedy komerčně úspěšný tiskařský artikl, který vycházel ročně v několikatisícových nákladech. ${ }^{57}$ Zatímco renesanční kalendáře známe také ve větším, kvartovém formátu, později převažují kapesní šestnácterky a dvanácterky. Vedle řady praktických informací (vlastní kalendár̆, seznamy jarmarků, řád zavírání městských bran, jízdní řády pošty, ale i dobově oblíbené astronomické údaje a $\mathrm{z}$ dnešního pohledu nedůvěryhodné předpovědi počasí, vlivy planet na zdraví člověka, vhodné dny pro pouštění žilou apod.) obsahovaly také historické zprávy, a především zábavnou složku, kterou tvořily př́běhy

\footnotetext{
${ }^{52}$ Na príkladu Znojemska ve 20.-30. letech 19. století sleduje BENEŠ 1994.

${ }^{53} \mathrm{~K}$ fenoménu obrozeneckých knížek lidového čtení srov. např. KRAMERIUS 1988. Bohatou literaturu na dané téma vyprodukovala Lenka Kusáková.

${ }^{54} \mathrm{~V}$ českém prostředí zatím chybí důkladnější výzkumy cenové hodnoty této produkce, ale z anglického prostředí víme, že broadside ballads se prodávaly za penci, small books za dvě pence, double-books za tři nebo čtyři pence a nejrozsáhlejší histories stály běžně šest pencí (NEWCOMB 2011, s. 474).

${ }^{55}$ Jen Knihopis (který není v př́padě kramářských tisků zdaleka vyčerpávajícím zdrojem) informuje o množství vydání z druhé poloviny 18 . století a přelomu 18. a 19. století (srov. knihopisná čísla 8352-8382).

${ }^{56} \mathrm{~K}$ písňovému zpracování př́iběhu o Jenovéfě krátce IVÁNEK 2011, s. 206-207.

${ }^{57}$ Srov. heslo Kalendár v online Encyklopedii knihy Petra Voita, dostupné z: www.encyklopedieknihy.cz (tam také bohatá literatura k tématu).
} 


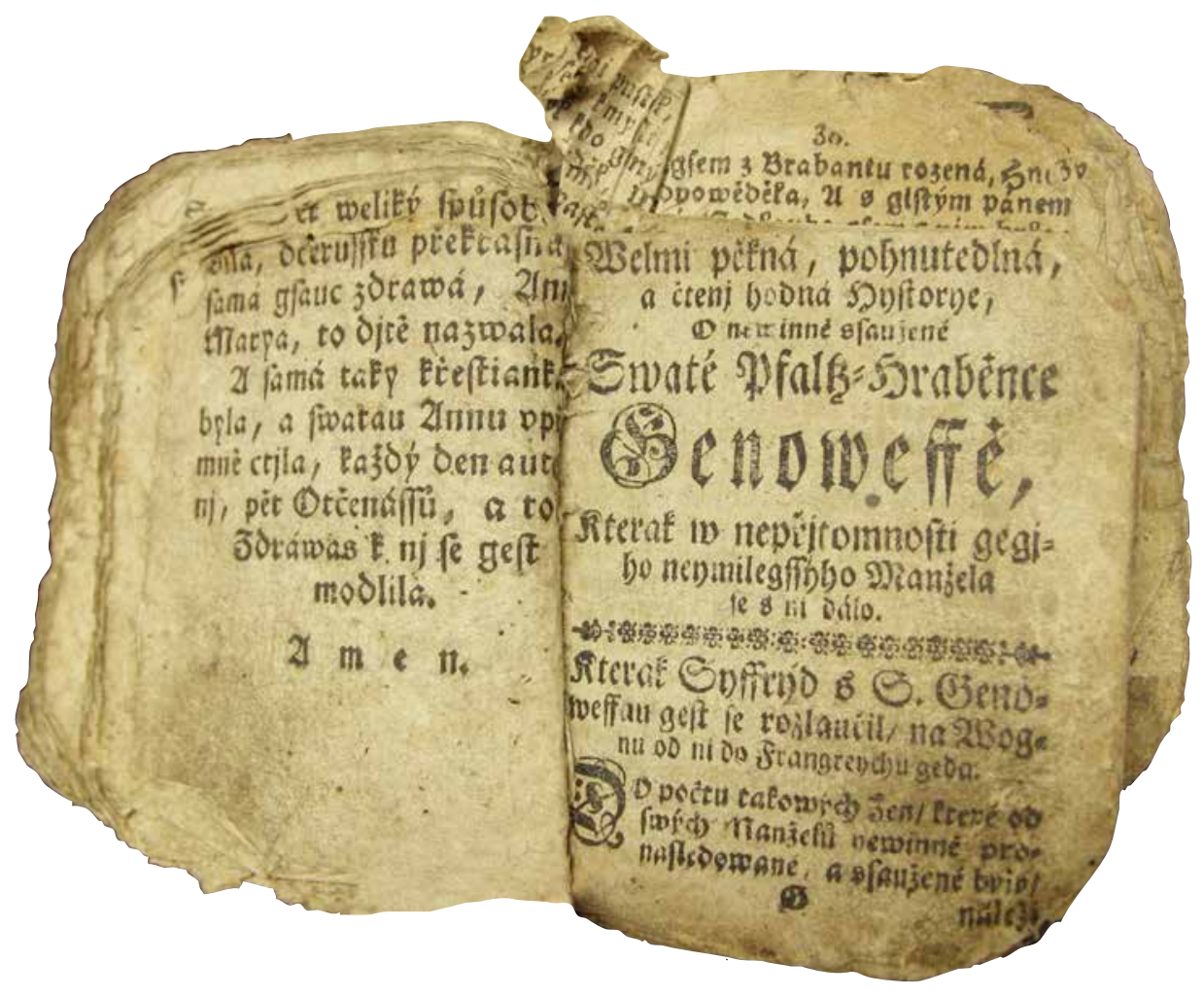

Obr. 15. Titulní strana př́běhu o sv. Jenovéfě na pokračování v kalendáři všitá do špalíčku kramářských písniček (Kapucínská provinční knihovna v Praze, 25 B 286, př́í.).

z knížek lidového čtení, legendy o světcích, případně katechetická próza. $V$ jednom ročníku kalendáře většinou nebyl prostor pro otištění celého díla, a tak nezř́ídka končilo vyprávění vydavatelskými formulemi podobnými následující: „Poněvádž toho roku pro nedostatek placu dálši vypravováni této historie jsem musel vypustiti, pročež dá Bůh přes rok o tom nètco více bude následovati. Vale. "58

Od přelomu 18. a 19. století se však v českém prostředí začínají objevovat také jednodušší, kratší verze lidového čtení v prozaické podobě. Jde o tzv. popisy či též výtahy a líčení, které vzešly z dobového zpravodajství. Krátké, samostatně vydávané př́iběhy, po vzoru německé tradice doplňované často shrnující závěrečnou písní, se u nás ve velkém rozmáhají ve druhé polovině 19 . století. Nejčastějším námětem jsou mnohačetné vraždy, osudy vězňů, rozsudky nad nimi a jejich popravy. ${ }^{59}$ Fascinaci soudními procesy vyčteme již na konci 18. století ve spisku o konci francouzského krále Ludvíka XVI., který parafrázuje jeho obhajobu i testament. Známe také popisy neštěstí či katastrof, pohnutých životních osudů, exotických krajin aj. Daný typ tisků může přinášet i výtahy z př́iběhů připomínajících starší i novější knížky lidového čtení. $S$ těmi se však nemohou rovnat rozsahem textů - obvykle mívají čtyři až osm listů (tedy osm až 16 stran) osmerkového formátu a bývají vsunuty či vlepeny do obálky s titulním listem a obrázkem, která bývá tištěna na barevném papíru. Souběžně však byly nadále publikovány i klasické, často více než stránkové knížky lidového čtení, $\mathrm{k}$ jejichž koupi dokonce vybízela reklama $\mathrm{v}$ závěru kratších tiskủ.

Existuje i duchovní opozice tohoto čtiva. Tvoří ji zejména samostatně vydávané životopisy světců a popisy poutních míst, mezi nimiž jsou nově vznikající lokality i tradičně navštěvovaná místa (Vambeřice, Varta, Jeruzalém). Ty většinou provázejí poutníka po městě a v závěru propagují další nábožné čtivo dané tiskárny, především modlitební knihy, které představují další z fenoménů kramářského zboží, jež se však knižním charakterem a značným rozsahem vymyká zařazení do oblasti kramářských tisků.

$\mathrm{Z}$ hraničních médií populární literatury si zaslouží zmínku také poutní příručky a kancionály. Knihy o poutních místech vznikaly po celé barokní období, ovšem dříve to bývala objemná sepsání s historicko-legendárními pasážemi i záznamy zázraků, někdy dokonce v latinském jazyce. Charakter populárního (třebaže vzhledem $\mathrm{k}$ rozsahu nikoli kramářského) tisku mají teprve praktické př́ručky sestavené z modliteb a písní vydávané od poloviny 18. století pro každoroční poutníky do rakouského Mariazell. Popularita těchto poutí vedla $\mathrm{k}$ masové, déle než století trvající oblibě a opakovaným edicím knih Žižnivý poutnik a Radostná cesta. ${ }^{60}$ Právě poutní knihy z tohoto období dokládají nejen rozvoj poutnictví v 18. století, ale také vzestup čtenářství

\footnotetext{
${ }^{58}$ Welmi pěkná, pohnutedlná a čtenj hodná Hystorye, O newinně ssaužené Swaté Pfaltz-Hraběnce Genoweffě, Kterak w nepřjtomnosti gegjho neymilegssýho Manžela se s ni dálo. Exemplář Kapucínské provinční knihovny v Praze (sign. 25 B 286, př́iv.) dokládá také zacházení uživatele $\mathrm{s}$ těmito př́iběhy vydávanými v kalendáŕích na pokračování, kdy byly zábavné texty z původního tisku vyjmuty a všity do špalíčku kramářských písní. ${ }^{59}$ SCHEYBAL 1962.

${ }^{60}$ Srov. MALURA - IVÁNEK 2019, s. 289-291.
} 


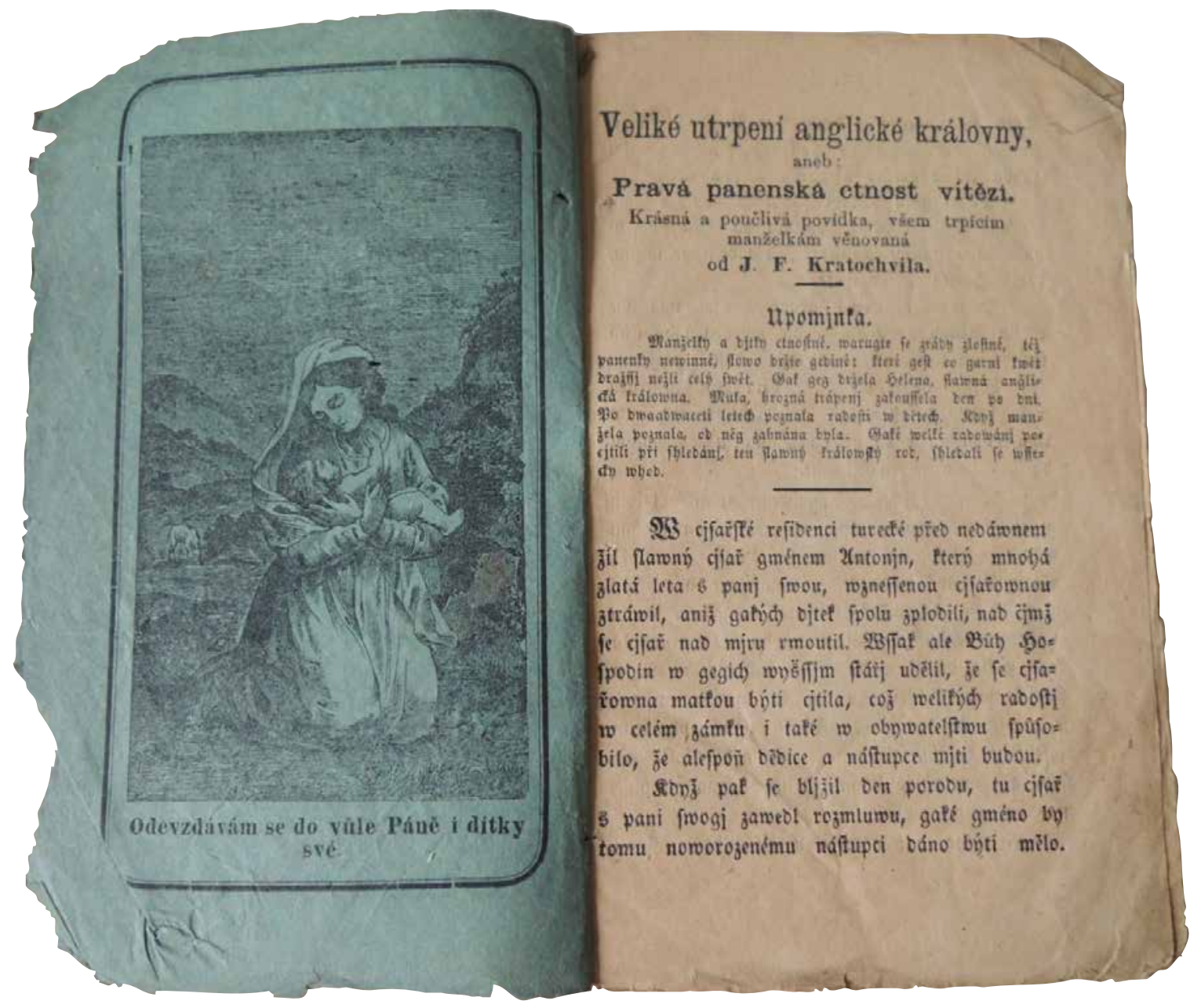

Obr. 16. Charakteristická podoba tisku tzv. popisu s barevnou obálkou. Kratochvíl, J. F.: Veliké utrpení anglické královny anebo Pravá panenská ctnost vítězí..., Chrudim 1873 (Knihovna Národního muzea, R. Hlava, KT 73).

(zprvu ve městech, později i na vsích) a čtenářské preference širokých vrstev obyvatelstva země.

Podobná situace panuje $\mathrm{v}$ oblasti kancionálů. Barokní kancionály byly vesměs náročné editorské i tiskařské počiny a zř́́dka vycházely opakovaně (výjimkou byly např. aktualizované reedice Šteyerova kancionálu). Situace se mění v průběhu 18. století, kdy vychází několikrát Cytara Nového zákona sestavená Antonínem Koniášem (poprvé 1727), jež patří spolu s Koniášovým německým zpěvníkem Lob-Klingende Harffe deß Neuen Testaments (1730) proklamativně $\mathrm{k}$ titulům, které měly být náhradou nekatolických zpěvníků, dosud šířených mezi lidmi. Ty už od 16. století pracovaly s kapesními formáty, nebot' počítaly (na rozdíl od katolických zpěvníků, jež se nacházely zpravidla na kostelních kůrech) také $\mathrm{s}$ individuální recepcí. I proto jsou Koniášovy zpěvníky menšího, osmerkového formátu. Do sféry populární, masové a tržní literatury pak plně spadají četná vydání zpěvníku Písně roční aneb Kancionálek, kterýžto netoliko při všech slavnostech celého roku, ale i každodenně se uživati může. Obsahuje penzum toho, co mohl věřící během církevního roku i v cyklu všedního dne využít. Vycházel v modifikovaných verzích ve většině tiskáren počínaje rokem 1738. Svým šestnácterkovým formátem sám připomínal špalíček kramářských písní a nejednou byl uživatelem do špalíčku všit. ${ }^{61}$

Př́ispěvek se zaměřil na problematiku poměrně širokého spektra kramářských tisků - média populární literatury raného novověku i 19. století - z nichž kramářské písně (v současnosti na výsluní badatelského zájmu) představují jen jedinou, třebaže nejobsáhlejšś složku. Obsah pojmu kramářrký tisk lze definovat také s pomocí jinonárodních ekvivalentů. Nejvýrazněji přispívá komparace s anglickým fenoménem chapbooks, které se s českými kramářrkými tisky setkávají také obsahem samotného termínu, jenž zrcadlí komerční zaměření této literatury (označení chapbooks můžeme doslovně přeložit jako „kramářské knížky“"). Ačkoli ani anglický termín nebývá vymezován jednoznačně, vesměs se badatelé shodují, že jde o rozsahem i formátem menší publikace sešitového charakteru (většinou osmerka či menší formát, vyrobený ze tří archů papíru nebo mající do 99 stran), které byly šířeny obchodníky na trzích a pouličním či podomním prodejem, byly levné, tedy cenově nenáročné (at' už mluvíme o jejich výrobě, či ceně, kterou za ně adresát zaplatil)

${ }^{61}$ Např. Horákův velký špalíček (Masarykův ústav, Archiv AV ČR) nebo špalíček ST 305 z Muzea Komenského v Přerově. 
a přinášely to, co si široké publikum městského a později i venkovského obyvatelstva žádalo - tedy populární čtivo v pravém slova smyslu. Komplikace přináší zejména zařazení tzv. knížek lidového čtení, jež odpovídají vesměs všem těmto charakteristikám, avšak rozsahem často překračují pomyslnou hranici 99 stran, vznikaly složením a spojením většího počtu tiskařských archů. Příspěvek se proto věnoval i některým médiím, která lze považovat za hraniční právě v tomto smyslu - tedy že rozsahem překračují definici kramářského zboží, ale z principu kramářským zbožím byly (tedy různě rozsáhlé publikace knižního charakteru malého formátu, ale šírené také na trzích či podomním obchodem). Text studie přibližuje také podobu a vývoj některých konkrétních typů kramářských tisků, a to náboženského i světského obsahu. Pro lepší názornost byly mnohé z těchto typů zprostředkovány i obrazem.

\section{Literatura:}

ATKINSON - ROUD 2019: ATKINSON, David - ROUD, Steve. Cheap Print and the People. European Perspectives on Popular Literature. Cambridge Scholars Publishing, 2019. BĚHALOVÁ 2003: BĚHALOVÁ, Štěpánka. Náboženský kramářský tisk a jeho recepce. In: RADIMSKÁ, Jitka (ed.). $K$ výzkumu zámeckých, měštanských a cirkevních knihoven. „Čtenár a jeho knihovna“. České Budějovice: Jihočeská univerzita, 2003, s. 547-558.

BENEŠ 1994: BENEŠ, Bohuslav. Komerční literatura v polovině 19. století na Znojemsku. In: Literatura a komerce. Olomouc: Vydavatelství Univerzity Palackého, 1994, s. 61-63.

BRANDTZAG - STRAND 2019: BRANDTZÆG, Siv Gøril - STRAND, Karin. The Scandinavian Skilling Ballad: A Transnational Cultural Heritage. In: ATKINSON - ROUD 2019, s. 139-169.

BROUČEK - JEŘÁBEK 2007: BROUČEK, Stanislav JEŘÁBEK, Richard (red.). Lidová kultura. Národopisná encyklopedie Čech, Moravy a Slezska. 2. svazek. Věcná část $A-N$. Praha: Mladá fronta, 2007.

BURKE 1978: BURKE, Peter. Popular Culture in Early Modern Europe. New York: Harper \& Row, 1978.

BURKE 1984: BURKE, Peter. Popular Culture between History and Ethnology. Ethnologia Europaea 14, 1984, S. 5-13.

BURKE 2005: BURKE, Peter. Lidová kultura v raně novověké Evropě. Trad. Markéta Křížová. Praha: Argo, 2005

DRAGONOVÁ - SZTURCOVÁ 2019: DRAGONOVÁ Martina - SZTURCOVÁ, Monika. Kramářské tisky ze sbirky Památníku Petra Bezruče Slezského zemského muzea v Opavě. Opava: Slezské zemské muzeum, 2019.

DROPPOVÁ - KREKOVIČOVÁ 2010: DROPPOVÁ, L'ubica - KREKOVIČOVÁ, Eva. Počujte panny, aj vy mládenci. Letákové piesne zo slovenských tlačiarní. Bratislava: Eterna Press, 2010.

DVOŘÁKOVÁ 2007: DVOŘÁKOVÁ, Hana. Devocionálie. In: BROUČEK - JEŘÁBEK (red.) 2007, s. 136-137.

FUMERTON - KOSEK - HANZELKOVÁ 2022: FUMERTON, Patricia - KOSEK, Pavel - HANZELKOVÁ, Marie (edd.). Czech Broadside Ballads as Multimedia Text,
Art, Song, and Popular Culture, c. 1600-1900. Amsterdam: Amsterdam University Press, 2022 (v př́ipravě).

GLOMBOVÁ 2020: GLOMBOVÁ, Hana (ed.). Do Brna široká cesta. Kramářské písně se světskou tematikou. Katalog k výstavě. Brno: Moravské zemské muzeum, 2020. HOLUBOVÁ 2003: HOLUBOVÁ, Markéta. Tištěná poutní produkce a její čtenář konzument. In: RADIMSKÁ, Jitka (ed.). K výzkumu zámeckých, měšt'anských a církevních knihoven. „Čtenár̆ a jeho knihovna“. České Budějovice: Jihočeská univerzita, 2003, s. 559-568.

HOLUBOVÁ 2012: HOLUBOVÁ, Markéta. Katalog kramářských tisků II. Biblická a křest'anská ikonografie. Praha: Etnologický ústav AV ČR, 2012.

HOLUBOVÁ 2017: HOLUBOVÁ, Markéta. Katalog kramářských tisků III. Německé kramářské tisky, jednolisty a kuplety. Praha: Etnologický ústav AV ČR, 2017.

HUBKOVÁ 2010: HUBKOVÁ, Jana. Fridrich Falcký $v$ zrcadle letákové publicistiky. Letáky jako pramen $k$ vývoji a vnímání české otázky v letech 1619-1632. Praha: Univerzita Karlova, Filozofická fakulta, 2010.

CHARVÁTOVÁ 2007: CHARVÁTOVÁ, Eva. Svaté obrázky. Čechy a Morava. Praha: Eminent, 2007.

CHUCHVAHA 2011: CHUCHVAHA, Hanna. Images, Words, and Book Production in the Russian Empire: Popular Prints, Lubok Books, and Illustrated Magazines. In: ATKINSON - ROUD 2019, s. 191-222.

IVÁNEK 2010: IVÁNEK, Jakub. Genologická analýza českých barokních písní o svatých. In: MALURA, Jan (ed.). Žánrové aspekty starší literatury. Ostrava: Ostravská univerzita, 2010, s. 121-147.

IVÁNEK 2011: IVÁNEK, Jakub. Zeitliche aktuelle Lieder von Heiligen unter tschechischen auf Märkten verkauften Drucken vom Ende des 17. bis den Anfang des 19. Jahrhunderts. In: VIDA, Beáta (ed.). Church and Ethnicity in History. First Year of Conference V4 for Doctoral Candidates in Ostrava. Ostrava: Ostravská univerzita, 2011, S. 202-211.

IVÁNEK 2017: IVÁNEK, Jakub. Poznámky k vymezení pojmu kramářská píseň (s ohledem na tisky náboženské povahy). Listy filologické 140, 2017, č. 1-2, s. 201-230.

KAFKA 2007a: KAFKA, Luboš. Škapulír. In: BROUČEKJEŘÁBEK 2007, s. 1028.

KAFKA 2007b: KAFKA, Luboš. Délka Ježíše Krista. In: BROUČEK - JEŘÁBEK 2007, s. 125-126.

KAFKA 2009: KAFKA, Luboš. Dárek z pouti. Poutni a pout’ové umění. Praha: Lika klub - Etnologický ústav AV ČR, 2009.

KLIMEKOVÁ 1996: KLIMEKOVÁ, Agáta (ed.). Bibliografia jarmočných a pútových tlači 18. a 19. storočia z územia Slovenska. Martin: Matica slovenská, 1996.

KOLÁR 2000: KOLÁR, Jaroslav (ed.). Tři knižky lidového čtení. Meluzína, Magelona, Jenovefa. Praha: Nakladatelství Lidové noviny, 2000.

KOLÁR 2004: KOLÁR, Jaroslav (ed.). Třikrát rozprávky o jednom hrdinovi. Ezop, Ejlenšpigel, Paleček. Praha: Nakladatelství Lidové noviny, 2004.

KOPALOVÁ - HOLUBOVÁ 2008: KOPALOVÁ, Ludmila - HOLUBOVÁ, Markéta. Katalog kramářských tiski̊. Praha: Etnologický ústav AV ČR, 2008. 
KRAMERIUS 1988: KRAMERIUS, Václav Rodomil. Knižky lidového čtení. Edd. Ondřej Hausenblas, Jaroslava Janáčková, Lenka Kusáková. Praha: Odeon, 1988.

KVAPIL 2001: KVAPIL, Jan. Ze zahrádky do zahrady aneb Od Hortulu animae $k$ Štěpné zahradě Martina z Kochemu. Utváření modlitební knihy barokního typu. Ústí nad Labem: Univerzita J. E. Purkyně, 2001.

LOUTHAN 2011: LOUTHAN, Howard. Obracení Čech na víru aneb Rekatolizace po dobrém a po zlém. Trad. Zdeněk Rucki. Praha: Rybka, 2011.

LUKAS - PÍŠA - WÖGERBAUER 2017: LUKAS, Jiří PÍŠA, Petr - WÖGERBAUER, Michael. Svaté obrázky. Pražská devoční grafika 18. a 19. století. Praha: Muzeum hlavního města Prahy, 2017.

MALURA - IVÁNEK 2019: MALURA, Jan - IVÁNEK, Jakub. Horo krásná, spanilá! Poutní písně na Moravě (1600-1850). Brno: Host, 2019.

MALURA 2019: MALURA, Jan. Počátky české kramářské písně v pozdním humanismu? Bohemica Olomucensia 11, 2019, č. 3, s. 18-36.

MALURA 2022: Where do Czech broadside ballads originate? In: FUMERTON - KOSEK - HANZELKOVÁ 2022 (v přípravě).

MIKOS - CSÖRSZ 2019: MIKOS, Éva-CSÖRSZ, Rumen István. Cheap Print in Eighteenth- and Nineteenth-Century Hungary. In: ATKINSON - ROUD 2019, s. 274-306.

MOUDRÝ 1942: MOUDRÝ, Miroslav. K charakteristice selského náboženství. Věstník české akademie zemědělské 18, 1942, s. 47-55, 146-157, 261-274.

NEWCOMB 2011: NEWCOMB, Lori Humphrey. Chapbooks. In: RAYMOND, Joad (ed.). The Oxford History of Popular Print Culture. Volume 1. Cheap Print in Britain and Ireland to 1660. New York: Oxford University Press, 2011, s. 471-490.

PETRTYL 1959: PETRTYL, Josef. Kramářské pověrečné tisky a jejich sociální působení v druhé polovině 19. století. Československá etnografie 7, 1959, č. 3, s. 291-307.
ROYT 2011: ROYT, Jan. Obraz a kult v Čechách 17. a 18. stoleti. Praha: Karolinum, 2011.

SCHEYBAL 1962: SCHEYBAL, Josef V. Typ lidových zpravodajských tisků v devatenáctém století. Československá etnografie 10, 1962, s. 265-280.

SINCLAIR 2019: SINCLAIR, Alison. Popular Literature in Spain: A Mouse's Tale. In: ATKINSON - ROUD 2019, s. 7-32.

SKOŘEPOVÁ 2016: SKOŘEPOVÁ, Markéta. Kramářské písně ze sbírky Muzea Vysočiny Pelhřimov. Pelhřimov: Muzeum Vysočiny, 2016.

SKOŘEPOVÁ 2019: SKOŘEPOVÁ, Markéta. Kramářské písně z Pelhřimovska. Pelhřimov: Muzeum Vysočiny, 2019. SPAMER 1930: SPAMER, Adolf. Das kleine Andachtsbild vom XIV. bis zum XX. Jahrhundert. München: F. Bruckmann, 1930.

VEČERKOVÁ 1999: VEČERKOVÁ, Eva. Pověrečné kramářské tisky ve sbírce Etnografického ústavu muzea v Brně. In: Tiskárny a tisky 19. století. Jindřichův Hradec: Okresní muzeum, 1999, s. 84-92.

\section{Internetové zdroje:}

Encyklopedie knihy. VOIT, Petr. Encyklopedie knihy v českém středověku a raném novověku [online]. Knihovna AV ČR. [Cit. 16. 6. 2021]. Dostupné z: www.encyklopedieknihy.cz Knihopis. Knihopis českých a slovenských tisků od doby nejstarši až do konce XVIII. století [online]. Národní knihovna ČR. [Cit. 16. 6. 2021]. Dostupné z: www.knihopis.cz

\author{
| Jakub Ivánek \\ Ostravská univerzita \\ Filozofická fakulta \\ Katedra české literatury a literární vědy \\ Reální 5 \\ 70103 Ostrava
}

